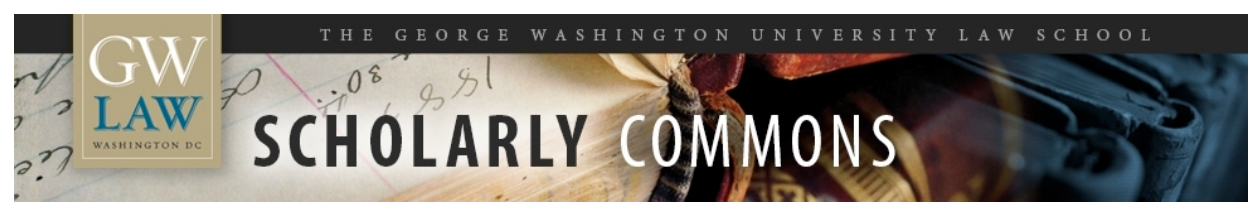

\title{
From Town Square to Twittersphere: The Public Forum Doctrine Goes Digital
}

Dawn C. Nunziato

George Washington University Law School, dnunziato@law.gwu.edu

Follow this and additional works at: https://scholarship.law.gwu.edu/faculty_publications

Part of the Law Commons

\section{Recommended Citation}

Nunziato, Dawn Carla, From Town Square to Twittersphere: The Public Forum Doctrine Goes Digital (September 14, 2018). 25 B.U. J. Sci. \& Tech. L. (2019), Forthcoming; GWU Legal Studies Research Paper No. 2018-40; GWU Law School Public Law Research Paper No. 2018-40. Available at SSRN:

https://ssrn.com/abstract=3249489

This Article is brought to you for free and open access by the Faculty Scholarship at Scholarly Commons. It has been accepted for inclusion in GW Law Faculty Publications \& Other Works by an authorized administrator of Scholarly Commons. For more information, please contact spagel@law.gwu.edu. 
From Town Square to Twittersphere:

The Public Forum Doctrine Goes Digital

- Professor Dawn Carla Nunziato ${ }^{1}$

forthcoming 25 B.U. J. Sci. \& Tech. L. (2019)

Minds are not changed in streets and parks as they once were. To an increasing degree, the more significant interchanges of ideas and shaping of public consciousness occur in mass and electronic media. The extent of public entitlement to participate in those means of communication may be changed as technologies change.... ${ }^{2}$

$\underline{\text { Introduction }}$

Government officials like President Donald J. Trump and Maryland Governor Larry Hogan are increasingly using popular social media sites like Twitter and Facebook to connect and interact with their constituents and to solicit public comment on matters of public importance - whether on officially-designated government platforms (like https://www.facebook.com/GovLarryHogan/33) or on unofficial platforms used for the same purposes. In recent years, government officials have increasingly turned to social media platforms like Twitter and Facebook in place of (and in addition to) actual town halls and other real-space forums to solicit public participation in policy formulation and to engage with their constituents. When such interactions between government officials and their constituents occur in real space like town halls, they fall comfortably within the scope of the First Amendment's public forum doctrine, which provides strong protections for freedom of speech and assembly,

\footnotetext{
${ }^{1}$ William Wallace Kirkpatrick Research Professor of Law, The George Washington University Law School; Co-Director, Global Internet Freedom and Human Rights Project. I am very grateful to Alexia Khella and Ken Rodriguez for providing excellent research and library assistance in connection with this article, to Kierre Hannon for excellent administrative assistance, and to Deans Naomi Cahn and Blake Morant for support of my research.

${ }^{2}$ Denver Area Educational Telecommunications Consortium v. F.C.C., 518 U.S. 727, 802-803 (1996) (Kennedy J., joined by Ginsburg, J., concurring in part, concurring in the judgment in part, and dissenting in part) (citations omitted).

${ }^{3}$ Governor Larry Hogan (@GovLarryHogan), FACEBOOK, https://www.facebook.com/GovLarryHogan.
} 
and prohibits government officials from discriminating against or silencing speakers based on their viewpoint. However, when such interactions take place in cyberspace -- on social media sites like Twitter and Facebook -- the application of the First Amendment's public forum is somewhat less clear. Social media sites like Twitter and Facebook are privately owned, which raises issues for the application of the First Amendment's public forum doctrine. The public forum doctrine (which provides the greatest protection for free speech in general, as well as against content and viewpoint discrimination) traditionally applies to government-owned or government-controlled -- not privately-owned -- property. The private ownership of social media sites also raises issues for the application of the First Amendment's state action doctrine, which provides that the restriction of speech by and through private actors does not implicate the First Amendment except in narrow, limited circumstances.

This Article examines whether and to what extent government officials' use of social media sites to interact with their constituents constitutes a public forum and what this forum analysis means for the ability of government officials to block or censor constituents on their social media sites. Such issues have recently arisen in the context of President Donald Trump's blocking of constituents with whom he disagrees on his @realDonaldTrump/Twitter account. Similar issues have arisen in the context of Maryland Governor Larry Hogan's and Virginia County Commissioner Phyllis Randall's blocking of constituents on their Facebook pages, in response to being asked challenging questions. ${ }^{4}$ The recent Supreme Court case of Packingham v. North Carolina ${ }^{5}$ sheds some light on the application of the public forum doctrine to social media sites and the use and misuse of such sites by government officials. In particular, Justice Kennedy's opinion for the Court in Packingham extends his functional, expansive conception of

\footnotetext{
${ }^{4}$ See text accompanying notes $\mathrm{x}-\mathrm{y}$.

${ }^{5}$ Packingham v. North Carolina, 137 S. Ct. 1730 (2017).
} 
the public forum doctrine to non-traditional forums that function as forums for public discourse. ${ }^{6}$ In Part I of this Article, I examine in detail the circumstances surrounding recent incidents in which government officials have blocked constituents from following them on Twitter and from commenting on their Facebook pages. Part II undertakes an analysis of the historical development of the public forum doctrine, its recent development in the digital age, as well as the government speech doctrine and the contrast between public forums and government speech. In Part III, I apply the forum analysis developed in Part II to the recent incidents of government officials' blocking constituents from accessing their social media sites, with an in-depth analysis of the Trump/Twitter lawsuit in particular, and conclude that such social media sites constitute public forums in which viewpoint discrimination is illegal. Part IV provides suggestions to government officials for developing policies governing social media accounts that comply with the dictates of the First Amendment, and a brief conclusion follows.

\section{The Issue: Government Officials' Use of Social Media to Interact with Constituents and to Block Constituents on the Basis of Viewpoint}

In recent years, government officials -- at the local, state, and national level -- have increasingly turned to social media sites like Facebook and Twitter to communicate and interact with their constituents. According to the Congressional Research Service, virtually all Members of Congress have at least one official congressional social media account. ${ }^{7}$ Officials have done so both from official government accounts and from unofficial accounts that they have utilized for government purposes. Maryland Governor Larry Hogan created an official Facebook page to make official announcements and to interact with his constituents, ${ }^{8}$ while County Commissioner Phyllis Randall of the Loudoun County Board of Supervisors created an unofficial Facebook

\footnotetext{
${ }^{6}$ Packingham, 137 S. Ct at 1735-36.

${ }^{7}$ See Jacob R. Straus \& MatTHEw E. Glassman, Cong. RESEARCH SERV., SOCIAL MEdia in CONGRESS: THE IMPACT OF ElECTRONIC MEDiA ON MEMBER COMMUNICATIONS, (2016).

${ }^{8}$ Governor Larry Hogan (@GovLarryHogan), FACEBOOK, https://www.facebook.com/GovLarryHogan.
} 
page for similar purposes. ${ }^{9}$ And President Donald Trump famously uses his Twitter account @realDonaldTrump (as well as, to a lesser extent, Twitter accounts @POTUS and @WhiteHouse) to interact with constituents and to provide official announcements on a variety of government policies. ${ }^{10}$ As the Supreme Court recently recognized in Packingham v. North Carolina, social media sites like Facebook and Twitter are ideal forums where "users can petition their elected representatives and otherwise engage with them in a direct manner."11 Problems arises, however, when government officials attempt to limit access to such forums and to restrict such forums to those who agree with them, while banning those who challenge or disagree with them -- as Hogan, Randall, and Trump have each recently done. ${ }^{12}$ Governor Hogan and Commissioner Randall blocked constituents who posted critical and challenging comments, ${ }^{13}$ while President Trump blocked citizens from following him on Twitter after they posted critical comments. ${ }^{14}$ In each case, the blocked users have sued the government officials, claiming that these platforms constituted public forums and that their First Amendment rights were violated by such actions. ${ }^{15}$ The government officials have responded that their social media accounts do not constitute public forums, that they are making personal not government use of such forums, that their speech is "government speech" immune from the dictates of the

\footnotetext{
${ }^{9}$ Chair Phyllis J. Randall, FACEBOOK, https://www.facebook.com/Chair-Phyllis-J-Randall1726409590911855.

${ }^{10}$ Donald J. Trump (@realDonaldTrump), TwITTER, https://twitter.com/realDonaldTrump.

${ }^{11}$ Packingham, 137 S. Ct at 1735.

${ }^{12}$ See text accompanying notes $\mathrm{x}-\mathrm{y}$.

${ }^{13}$ See e.g., Ovetta Wiggins \& Fenit Nirappil, Gov. Hogan's Office Has Blocked 450 People From His Facebook Page in Two Years, WASH. PosT (Feb. 2, 2017), https://www.washingtonpost.com/local/md-politics/gov-hogans-office-has-blocked-450-people-from-hisfacebook-page-in-two-years/2017/02/08/54a62e66-ed45-11e6-9973c5efb7ccfb0d_story.html?utm_term=.a9e0287239ed.

${ }^{14}$ See e.g., Nancy Coleman, It Doesn't Take Much for Trump to Block You On Twitter, CNN (June 9, 2017, 9:09 AM), https://www.cnn.com/2017/06/09/politics/trump-twitter-block-users-trnd/index.html. ${ }^{15}$ See Complaint at 3, Laurenson et al. v. Hogan, No. 8:17 Civ. 02162-DKC (filed on Aug. 1, 2017); Complaint at 2-3, Knight First Amendment Inst. at Columbia Univ. v. Trump, 302 F. Supp. 3d 541 (S.D.N.Y. 2018) (No. 1:17 Civ. 05205).
} 
Free Speech Clause, and that in any case they enjoy the discretion to block citizens' access to these accounts and delete users' posts from these accounts. ${ }^{16}$ Below I turn to the details of each of these cases to develop a better understanding of the First Amendment interests at stake.

A. Maryland Governor Larry Hogan Blocks Constituents and Deletes Their Comments From His Official Facebook Page

Maryland governor Larry Hogan established an official Facebook page -- available at https://www.facebook.com/GovLarryHogan -- as a means of communicating directly and interacting with his constituents. ${ }^{17}$ Governor Hogan uses his Facebook page as a vehicle to promote his positions on policy issues, to engage with his constituents, and to share information about his official activities as governor. ${ }^{18}$ Hogan's official Social Media Policy indicated that his Facebook page was established "to promote and disseminate information on Governor Larry Hogan's initiatives, events, and personal announcements" and to serve as a "forum for constructive and respectful discussion with and among users." ${ }^{19}$ However, this Policy also provided that constituents' comments on Hogan's Facebook page may be deleted if they are "inappropriate" or not on-topic, and further, that comments can be deleted -- and constituents can be blocked -- "at any time without prior notice or without providing justification." 20

Since establishing his Facebook page, Hogan has blocked over 450 people from accessing his Facebook page after these people posted comments that the governor apparently

\footnotetext{
${ }^{16}$ See Hogan Answer; Motion of Government for Summary Judgment at 13-22, Knight First Amendment Inst. at Columbia Univ. v. Trump, 302 F. Supp. 3d 541 (S.D.N.Y. 2018) (No. 1:17 Civ. 05205).

${ }^{17}$ Governor Larry Hogan (@GovLarryHogan), FACEBOOK, https://www.facebook.com/GovLarryHogan. ${ }^{18}$ See Ovetta Wiggins, Why Maryland Gov. Larry Hogan Uses Facebook Much More Than Twitter, Wash. Post (Dec. 4, 2015), https://www.washingtonpost.com/local/md-politics/why-maryland-gov-larryhogan-uses-facebook-much-more-than-twitter/2015/12/04/7762554a-87bd-11e5-be390034bb576eee_story.html?utm_term=.c86e897d0ce9 (“'The governor views social media, especially Facebook, as a way to talk directly to the people of this state without the interference of traditional media,' Hogan spokesman Doug Mayer said. . . Hogan and his communications staff post to Facebook multiple times a day....”).

${ }^{19}$ Exhibit A to Complaint, Laurenson et al. v. Hogan, No. 8:17 Civ. 02162-DKC (filed on Aug. 1, 2017).

${ }^{20}$ Exhibit A to Complaint, Laurenson et al. v. Hogan, No. 8:17 Civ. 02162-DKC (filed on Aug. 1, 2017).
} 
viewed as challenging or critical of him. ${ }^{21}$ About half of these people were blocked after the 2015 protests in Baltimore related to the controversial police-involved killing of Freddie Gray as well as following the January 2017 issuance of President Trump's executive order known as the Muslim ban. ${ }^{22}$

In one such case, Meredith Phillips -- a Maryland citizen and former Democrat who crossed party lines to vote Republican for Governor Hogan -- was blocked from Hogan's Facebook page after she posted a comment on the page asking Hogan to make a public statement about President Trump's Muslim ban. ${ }^{23}$ Phillips was concerned that Maryland residents had not heard from Governor Hogan on the issue of Trump's recently-announced Muslim ban and sought to hear from the governor on the issue. ${ }^{24}$ In Phillips's first comment on Hogan's Facebook page on January 29, 2017 -- two days after President Trump issued the Muslim Ban -- Phillips asked whether Governor Hogan planned to "speak out on the Muslim ban." ${ }^{25}$ Meredith posted her comment in response to Hogan's then-most-recent post on his Facebook page. ${ }^{26}$ A few hours after posting her comment requesting that Hogan make a public statement about the Muslim ban, Phillips noticed that her comment had been deleted. ${ }^{27}$ Shortly thereafter, Phillips re-posted her

\footnotetext{
${ }^{21}$ See Ovetta Wiggins \& Fenit Nirappil, Gov. Hogan's Office Has Blocked 450 People From His Facebook Page in Two Years, WASH. POST (Feb. 2, 2017), https://www.washingtonpost.com/local/mdpolitics/gov-hogans-office-has-blocked-450-people-from-his-facebook-page-in-twoyears/2017/02/08/54a62e66-ed45-11e6-9973c5efb7ccfb0d_story.html?utm_term=.a9e0287239ed(attributing half of the blocks to "hateful or racist" language, according to Hogan's spokesman).

${ }^{22}$ See Ovetta Wiggins \& Fenit Nirappil, Gov. Hogan's Office Has Blocked 450 People From His Facebook Page in Two Years, WASH. PosT (Feb. 2, 2017), https://www.washingtonpost.com/local/mdpolitics/gov-hogans-office-has-blocked-450-people-from-his-facebook-page-in-twoyears/2017/02/08/54a62e66-ed45-11e6-9973c5efb7ccfb0d_story.html?utm_term=.a9e0287239ed(attributing half of the blocks to "hateful or racist" language, according to Hogan's spokesman).

${ }^{23}$ See Complaint at 11, Laurenson et al. v. Hogan, No. 8:17 Civ. 02162-DKC (filed on Aug. 1, 2017).

${ }^{24}$ See Complaint at 12, Laurenson et al. v. Hogan, No. 8:17 Civ. 02162-DKC (filed on Aug. 1, 2017).

${ }^{25}$ See Complaint at 11, Laurenson et al. v. Hogan, No. 8:17 Civ. 02162-DKC (filed on Aug. 1, 2017).

${ }^{26}$ See Complaint at 11, Laurenson et al. v. Hogan, No. 8:17 Civ. 02162-DKC (filed on Aug. 1, 2017).

${ }^{27}$ See Complaint at 11, Laurenson et al. v. Hogan, No. 8:17 Civ. 02162-DKC (filed on Aug. 1, 2017).
} 
comment, adding that she "crossed party lines to vote for [Hogan]" and stating that she hoped Hogan would "stand up for all Marylanders and not just those that agree with [Hogan]."28 A few hours after posting her second comment, Phillips observed that this comment had been deleted as well. ${ }^{29}$ When Phillips attempted to re-post her comment for a third time, she found that she was restricted outright from doing so. ${ }^{30}$ Phillips further observed that posts similar to hers were deleted from Hogan's Facebook page, while posts ridiculing citizens who were concerned about the Muslim ban were allowed to remain on the Facebook page. ${ }^{31}$ Phillips raised her concerns with the Governor's Office, but remained blocked from posting comments on Governor Hogan's official Facebook page. ${ }^{32}$

Molly Handley, a resident of Maryland at the time in question, also had her comments on the Muslim ban deleted from Governor Hogan's Facebook page. ${ }^{33}$ Soon after President Trump announced the Muslim ban, Handley posted comments on Hogan's Facebook page asking Hogan to make a public statement regarding the ban and urging others to call and ask the governor about his position on the topic. ${ }^{34}$ Her comments were deleted the same day that she posted them, and Handley also observed that other similar comments regarding the Muslim ban were deleted. $^{35}$

Similarly, Maryland resident James Laurenson made comments challenging Hogan's policies on Hogan's Facebook page and had his comments deleted. ${ }^{36}$ In the fall of 2015, Laurenson posted several comments on Hogan's Facebook page on the topic of the Syrian

\footnotetext{
${ }^{28}$ Complaint at 11, Laurenson et al. v. Hogan, No. 8:17 Civ. 02162-DKC (filed on Aug. 1, 2017).

${ }^{29}$ See Complaint at 11, Laurenson et al. v. Hogan, No. 8:17 Civ. 02162-DKC (filed on Aug. 1, 2017).

${ }^{30}$ See Complaint at 11, Laurenson et al. v. Hogan, No. 8:17 Civ. 02162-DKC (filed on Aug. 1, 2017).

${ }^{31}$ See Complaint at 12, Laurenson et al. v. Hogan, No. 8:17 Civ. 02162-DKC (filed on Aug. 1, 2017).

${ }^{32}$ See Complaint at 12-13, Laurenson et al. v. Hogan, No. 8:17 Civ. 02162-DKC (filed on Aug. 1, 2017).

${ }^{33}$ See Complaint at 14, Laurenson et al. v. Hogan, No. 8:17 Civ. 02162-DKC (filed on Aug. 1, 2017).

${ }^{34}$ See Complaint at 14, Laurenson et al. v. Hogan, No. 8:17 Civ. 02162-DKC (filed on Aug. 1, 2017).

${ }^{35}$ See Complaint at 14, Laurenson et al. v. Hogan, No. 8:17 Civ. 02162-DKC (filed on Aug. 1, 2017).

${ }^{36}$ See Complaint at 9, Laurenson et al. v. Hogan, No. 8:17 Civ. 02162-DKC (filed on Aug. 1, 2017).
} 
refugee crisis, asking the governor to reconsider his request to the Obama Administration to not allow Syrian refugees into Maryland. ${ }^{37}$ In his comments, Laurenson stated his opinion that turning away Syrians was the wrong response and could even be perceived by ISIS as anti-Arab and anti-Muslim, which could be used by ISIS against the West. ${ }^{38}$ After Laurenson made these comments, his comments were deleted from Hogan's Facebook page and Laurenson was blocked from posting any further comments on the page. ${ }^{39}$

As a consequence of being blocked from Hogan's Facebook page, these constituents were unable to engage with Governor Hogan and his other constituents regarding matters of public importance relating to Hogan's governance.

\section{B. Loudoun County, Virginia, Commissioner Phyllis J. Randall Deletes Constituent's Critical Comments from her Unofficial Facebook Page}

Phyllis Randall is the Chair of the Loudoun County, Virginia, Board of Supervisors, ${ }^{40}$ which is the branch of local government responsible for adopting policies and ordinances and appropriating funds for Loudoun County, Virginia. ${ }^{41}$ Randall set up a Facebook page -- the “Chair Phyllis J. Randall” Facebook page -- to interact with her constituents. ${ }^{42}$ She titled her Facebook page "Chair Phyllis J. Randall, Government Official," and in the About section of the page, she included her title "Chair of the Loudoun County Board of Supervisors" and provided links to Loudoun County's official website featuring her profile. ${ }^{43}$ The Facebook page featured images of Randall in front of a United States flag with a plaque inscribed "Phyllis J. Randall

\footnotetext{
${ }^{37}$ See Complaint at 9, Laurenson et al. v. Hogan, No. 8:17 Civ. 02162-DKC (filed on Aug. 1, 2017).

${ }^{38}$ See Complaint at 9, Laurenson et al. v. Hogan, No. 8:17 Civ. 02162-DKC (filed on Aug. 1, 2017).

${ }^{39}$ See Complaint at 10, Laurenson et al. v. Hogan, No. 8:17 Civ. 02162-DKC (filed on Aug. 1, 2017).

${ }^{40}$ See Davison v. Loudoun Cnty. Bd. of Supervisors, 267 F. Supp. 3d 702, 707 (E.D. Va. May 10, 2017).

${ }^{41}$ See Board of Supervisors, VIRGINIA LOUDOUN COUNTY, https://www.loudoun.gov/bos (last visited July 29, 2018).

42 See Davison, 267 F. Supp. 3d at 707.

${ }^{43}$ See Davison, 267 F. Supp. 3d at 707-08.
} 
Chair-At-Large." ${ }^{44}$ On her Facebook page, Randall expressly solicits "back and forth" communications with and interactions from her constituents and indicates that the page is to be a channel through which her constituents should reach out to her and interact with her. ${ }^{45}$ On this Facebook page, she indicates: "Everyone, could you do me a favor. I really want to hear from ANY Loudoun citizen on ANY issues, request, criticism, compliment, or just your thoughts. .... I really try to keep back and forth conversations ... on my county Facebook page..." ${ }^{46}$ Although she sought to use this Facebook page as a platform for interacting with her constituents, Randall apparently chose to set up the page outside of the County's official channels so that she would not be constrained by the policies applicable to County social media websites. ${ }^{47}$ Many of the posts on her Facebook page involve Randall's work as Chair of the Loudoun County Board of Supervisors and are specifically addressed to her constituency. ${ }^{48}$

In February 2016, Randall participated in a (real space) town hall discussion hosted by the Loudoun County Board of Supervisors and the Loudoun County School Board. ${ }^{49}$ Brian Davison, a constituent and critic of Randall, attended the panel discussion and anonymously submitted two questions for discussion during the town hall, one of which was selected for submission to the panel, which concerned Randall's proposal for an ethics pledge for public servants. ${ }^{50}$ In his question, Davison asked whether School Board members - who Davison believed had acted unethically - should be required to take such an ethics pledge. ${ }^{51}$ Randall answered the question at the town hall, which she characterized as a "set-up question, " but

\footnotetext{
${ }^{44}$ See Davison v. Loudoun Cnty. Bd. of Supervisors, 227 F. Supp. 3d 605, 610-11 (2017).

${ }^{45}$ See Davison, 267 F. Supp. 3d at 708.

${ }^{46}$ Davison, 267 F. Supp. 3d at708.

${ }^{47}$ See Davison, 267 F. Supp. 3d at707.

${ }^{48}$ See Davison, 267 F. Supp. 3d at709-10 ("Many - perhaps most - of the posts . . . are expressly addressed to "Loudoun” - Defendant's constituents.").

${ }^{49}$ See Davison, 267 F. Supp. 3d at710.

${ }^{50}$ See Davison, 267 F. Supp. 3d at710.

${ }^{51}$ See Davison, 267 F. Supp. 3d at 710.
} 
Davison found her answer to be inadequate. After Randall responded to his question during the town hall, Davison tweeted a message at Randall, which read: “@ChairRandall ‘set up question'? You might want to strictly follow FOIA [the Freedom of Information Act] and the COIA [the Conflicts of Interest Act] as well." ${ }^{\text {52 }}$ Later that evening, Randall posted about the panel discussion on her Facebook page. ${ }^{53}$ Davison, persistent in his criticisms of Randall, posted a related comment on Randall's Facebook page, in which he continued to advance allegations of corruption on the part of Loudoun County's School Board and alleged conflicts of interest on the part of School Board members. ${ }^{54}$

Randall took issue with Davison's comments on her Facebook page regarding Loudoun County School Board members and chose to delete her original post about the panel discussion and Davison's comment as well. ${ }^{55}$ Randall also chose to ban Davison from her Facebook page. ${ }^{56}$ As a consequence of being banned from Randall's Facebook page, Davison could not comment on Randall's posts in a manner that was accessible by all of Randall's constituents who followed her on that page, nor could he send messages to Randall via her Facebook page. ${ }^{57}$ C. President Donald Trump Blocks Individuals from Following his Twitter Account

President Donald Trump makes extensive use of Twitter and, in particular, of his Twitter account @realDonaldTrump. ${ }^{58}$ Although Trump and his administration also make use of other

\footnotetext{
${ }^{52}$ See Davison, 267 F. Supp. 3d at 710.

${ }^{53}$ See Davison, 267 F. Supp. 3d at 710.

${ }^{54}$ See Davison, 267 F. Supp. 3d at 711.

${ }^{55}$ See Davison, 267 F. Supp. 3d at 711.

${ }^{56}$ See Davison, 267 F. Supp. 3d at 711.

${ }^{57}$ See Davison, 267 F. Supp. 3d at 711. Davison could, however, still read content posted on Randall's Facebook page, since it was available to the general public. Id. The following morning, however, Randall reconsidered her decision to ban Davison from her Facebook page and unbanned him. Id. Accordingly, Davison was only banned from Randall's website for approximately a 12 hour period, at most. Id.

${ }^{58}$ See e.g., Donald J. Trump, Twitter Counter, https://twittercounter.com/realDonaldTrump (last updated July 14, 2018); Amanda Wills \& Alysha Love, All the President's Tweets, CNN, http://www.cnn.com/interactive/2017/politics/trump-tweets (last updated July 14, 2018).
} 
Twitter accounts -- including @POTUS and @WhiteHouse -- Trump primarily communicates to the public via his @realDonaldTrump [@RDT] Twitter account. ${ }^{59}$ (Indeed, both the @WhiteHouse account and the @POTUS account indicate that people should follow these accounts "for the latest from President @realDonaldTrump and his Administration," suggesting that the @RDT account is the primary source of communications relating to the Trump Administration. ${ }^{60}$ Although Trump established the @RDT account in 2009 prior to being elected president, Trump now uses this account as his primary channel for communicating with the public about matters related to his administration and his presidency ${ }^{61}$ Prior to being elected president, Trump used his @RDT account to tweet about a variety of topics -- like golf, popular culture, and politics. ${ }^{62}$ However, since his inauguration in January 2017, Trump has used the @RDT predominantly to communicate about matters related to his presidency and his administration. ${ }^{63}$ In addition, Trump has set up his @RDT account in a manner that indicates

${ }^{59}$ See e.g., Mike Snider, Is Trump's Blocking of Some

Twitter Users Unconstitutional?, USA TODAY (June 6, 2017, 3:26 PM), https://www.usatoday.com/story/tech/news/2017/06/06/trumps-blocking-some-twitter-usersunconstitutional/102549854 (describing the President's use of the @RDT account as “unprecedented”). ${ }^{60}$ The While House (@WhiteHouse), TwITTER, https://twitter.com/WhiteHouse. See President Trump (@POTUS), TwITTER, https://twitter.com/potus(linking to the @RDT account in the account description).

${ }^{61}$ See Robert Loeb, Blocking Twitter Users From the Presidential Account, LAWFARE (June 13, 2017, 5:31 PM), https://www.lawfareblog.com/blocking-twitter-users-presidential-account-0 ("The President . . . uses his @realDonaldTrump account to speak to matters as President of the United States. He speaks to acts of foreign countries, court decisions, legislative proposals, posts video of cabinet meetings, and expresses his views as President on a host of public policy issues. . This is not merely a personal social media account where Mr. Trump posts birthday greetings to friends and family.”).

${ }^{62}$ See e.g., Monica Sisavat, Here Are Those Tweets Donald Trump Wrote About Kristen Stewart and Robert Pattinson, POPSUGAR (Feb. 5, 2017), https://www.popsugar.com/celebrity/Donald-Trump-2012Tweets-About-Kristen-Stewart-43112386 (tracking a series of @RDT tweets of Trump commenting on Twilight star Kristen Stewart and her relationship with co-star Robert Pattinson).

${ }^{63}$ See Alex Abdo, @realDonaldTrump and the First Amendment, KNIGHT FIRST AMENDMENT InstituTE AT COLUMBIA UNIVERSITY (June 19, 2017), https://knightcolumbia.org/news/realdonaldtrump-and-firstamendment ("The President uses the [@RDT] account almost exclusively to communicate about government affairs, including international affairs, economic policy, and appointments to senior government positions. This is not an account focused on personal interests, say, television, golf courses, or family.”). 
that it is the official account associated with his presidency. The account is registered to Donald Trump, "45th President of the United States of America, Washington, D.C.," and the header pictures associated with the account show images of President Trump performing his official duties. ${ }^{64}$

President Trump tweets frequently from his @RDT account to make announcements and to engage in advocacy efforts related to his administration and his presidency. Notably, Trump uses his@RDT account far more frequently than he uses the @POTUS account or the @WhiteHouse to communicate with the public. ${ }^{65}$ His then-Press Secretary Sean Spicer stated that tweets from President Trump should be understood as "official statements by the President of the United States"66 and his social media director Dan Scavino has indicated that all three Twitter accounts associated with his presidency -- @realDonaldTrump, @POTUS, and @WhiteHouse -- are channels through which "President Donald J. Trump ... communicates with you, the American people!"67 Trump has used his @realDonalTrump account on a daily basis for a variety of official governmental purposes: "to announce, describe, and defend his policies; to promote his Administration’s legislative agenda; to announce official decisions; to engage with foreign political leaders; to publicize state visits; to challenge media organizations whose coverage of his Administration he believes to be unfair" (among other purposes). ${ }^{68}$ For

\footnotetext{
${ }^{64}$ Donald J. Trump (@realDonaldTrump), TwITTER, https://twitter.com/realDonaldTrump

${ }^{65}$ As of this writing, the @RDT account has about 38,000 tweets, while the @POTUS account has about 3,000 tweets and the @WhiteHouse account has about 4,500 tweets. Compare Donald J. Trump (@realDonaldTrump), TwITTER, https://twitter.com/realDonaldTrump, with President Trump (@POTUS), TwITTER, https://twitter.com/potus, and The White House (@WhiteHouse), TwITTER, https://twitter.com/WhiteHouse.

${ }^{66}$ See Ali Vitali, Trump's Tweets 'Official Statements,' Spicer Says, NBC NEws (June 6, 2017, 5:02 PM), https://www.nbcnews.com/politics/white-house/trump-s-tweets-official-statements-spicer-says-n768931.

${ }^{67}$ Dan Scavino Jr. (@Savino45), TwITTER (June 6, 2017, 3:39 PM), https://twitter.com/scavino45/status/872221311090778114?lang=en.

${ }^{68}$ Complaint at 14, Knight First Amendment Inst. at Columbia Univ. v. Trump, 302 F. Supp. 3d 541

(S.D.N.Y. 2018) (No. 1:17 Civ. 05205)
} 
example, Trump used this account to announce his intention to nominate Christopher Wray for the position of FBI director, ${ }^{69}$ to remove then-Secretary of State Rex Tillerson from his position, ${ }^{70}$ and to remove then-Secretary of Veterans Affairs David Shulkin from his position. ${ }^{71}$ Trump also used his @RDT account as a vehicle to announce that the United States Government would no longer accept or allow transgender individuals to serve in the military. ${ }^{72}$ Federal courts regard tweets from @RDT as official statements by and from the president. For example, the U.S. Court of Appeals for the Ninth Circuit cited the president's tweets from his @RDT account in striking down Executive Order 13,780, which temporarily suspended nationals of certain

${ }^{69}$ See Donald J. Trump (@realDonaldTrump), TwITTER (June 7, 2017, 4:44 AM), https://twitter.com/realdonaldtrump/status/872419018799550464?lang=en (tweeting, "I will be nominating Christopher A. Wray, a man of impeccable credentials, to be the new Director of the FBI. Details to follow”).

${ }^{70}$ See Donald J. Trump (@realDonaldTrump), TwITTER (Mar. 13, 2018 5:44 AM), https://twitter.com/realDonaldTrump/status/973540316656623616?ref_src=twsrc\%5Etfw\%7Ctwcamp\%5 Etweetembed\%7Ctwterm\%5E973540316656623616\&ref url=https\%3A\%2F\%2Fmashable.com\%2F201 8\%2F03\%2F13\%2Frex-tillerson-fired-twitter\%2F (tweeting, "Mike Pompeo, Director of the CIA, will become our new Secretary of State. He will do a fantastic job! Thank you to Rex Tillerson for his service!”).

${ }^{71}$ See Donald J. Trump (@realDonaldTrump), TwITTER (Mar. 28, 2018, 2:31 PM), https://twitter.com/realdonaldtrump/status/979108653377703936?lang=en (tweeting, "I am pleased to announce that I intend to nominate highly respected Admiral Ronny L. Jackson, MD, as the new Secretary of Veterans Affairs....”); Donald J. Trump (@realDonaldTrump), TwITTER (Mar. 28, 2018, 2:31 PM), https://twitter.com/realDonaldTrump/status/979108846408003584 (tweeting, “....In the interim, Hon. Robert Wilkie of DOD will serve as Acting Secretary. I am thankful to Dr. Shulkin's service to our country and to our GREAT VETERANS!”).

72 See Donald J. Trump (@realDonaldTrump), TwITTER (July 26, 2017, 5:55 AM), https://twitter.com/realDonaldTrump/status/890193981585444864?ref_src=twsrc\%5Etfw\%7Ctwcamp\%5 Etweetembed\%7Ctwterm\%5E890193981585444864\&ref url=https\%3A\%2F\%2Fwww.theatlantic.com\% 2Fpolitics\%2Farchive\%2F2017\%2F11\%2Fpricking-of-his-thumbs\%2F544547\%2F (tweeting, "After consultation with my Generals and military experts, please be advised that the United States Government will not accept or allow......”); Donald J. Trump (@realDonaldTrump), TwITTER (July 26, 2017, 6:04 AM),

https://twitter.com/realDonaldTrump/status/890196164313833472?ref_src=twsrc\%5Etfw\%7Ctwcamp\%5 Etweetembed\%7Ctwterm\%5E890196164313833472\&ref_url=https\%3A\%2F\%2Fwww.theatlantic.com\% 2Fpolitics\%2Farchive\%2F2017\%2F11\%2Fpricking-of-his-thumbs\%2F544547\%2F (tweeting, “....Transgender individuals to serve in any capacity in the U.S. Military.”). 
countries from entering the United States. ${ }^{73}$ In addition, the United States Supreme Court

recently referenced the president's tweets in its 5-4 decision upholding the revised Muslim travel ban. $^{74}$

Trump's @RDT Twitter account is generally accessible and open to the public, without regard to political affiliation, ideological position, or viewpoint. ${ }^{75}$ As of this date, the account has approximately 53 million followers and President Trump has not (generally) limited who can access to his account or what people can say in response to his tweets. ${ }^{76}$ Trump's tweets from the @RDT account generally attract a large number of comments from those who follow the account on Twitter. ${ }^{77}$ Followers are able to interact with and engage with the president's tweets in a number of ways. First, followers can view the president's tweets (as can anyone with access to Twitter). Second, followers of @RDT can retweet his tweets. Third, followers can "like" his tweets. Fourth, and most significantly for purposes of this Article, followers can reply to his tweets. $^{78}$ The president's tweets from @RDT generally garner a substantial amount of

\footnotetext{
${ }^{73}$ See Hawaii v. Trump, 859 F.3d 741, 773 n.14 (9th Cir. 2017) (citing Donald J. Trump (@realDonaldTrump), Twitter (June 5, 2017, 6:20 PM, https://twitter.com/realDonaldTrump/status/871899511525961728).

${ }^{74}$ In Trump v. Hawaii, both the majority and the dissent refer to Trump's tweets regarding the Muslim ban in analyzing the constitutionality of the Executive Order at issue. 138 S. Ct. 2392, 2417, 2437-3 (2018). See also Brian Fung, The Supreme Court's Travel Ban Ruling Could Have Big Implications For Trump's Twitter Account, WASH. POST (June 26, 2018), https://www.washingtonpost.com/technology/2018/06/26/supreme-courts-travel-ban-ruling-could-havebig-implications-trumps-twitter-account/?utm_term=.07adab122704 ("Both in the opinion and the dissents, the Justices consistently adopted the perspective that Trump's broadcasts on Twitter are an official reflection of the White House -- not merely the personal feelings of a private individual, as the government has claimed elsewhere.”).

75 See Donald J. Trump (@realDonaldTrump), TwITTER, https://twitter.com/realDonaldTrump.

${ }^{76}$ See Donald J. Trump (@realDonaldTrump), TwITTER, https://twitter.com/realDonaldTrump.

${ }^{77}$ See also Ashley Hoffman, President's Trump's Top Tweets of All Time Show a Stark Divide, TIME (Apr. 28, 2017), http://time.com/4758366/trump-most-popular-tweets-ever (tracking Trump’s most popular tweets).

${ }^{78}$ See e.g., Charlie Warzel, Inside the Chaotic Battle to be the Top Reply to a Trump Tweet, BUZZFEED (June 9, 2017, 1:31 PM), https://www.buzzfeed.com/charliewarzel/trollpotusgrowthhack?utm_term=.eoV5gYveO\#.nivZP6gko
} 
engagement from members of the public, with typical responses including tens of thousands of replies. ${ }^{79}$ For example, within the three hour period after Trump tweeted his ban on transgender individuals in the military, the three tweets announcing the change in policy had been retweeted approximately 121,000 times, liked 382,000 times, and replied to 142,000 times. $^{80}$ Replies to tweets on Twitter are iterative, and include replies to an initial tweet, as well as replies to replies. This interactive and iterative thread of commentary related to a particular tweet is referred to as the "comment thread," which includes multiple overlapping comments and responses among Twitter users. Each tweet from the president's @RDT account engenders an extensive interactive response from members of the public who follow the president's account on Twitter, with thousands of retweets, likes, and replies composing an extensive and detailed iterative comment thread. ${ }^{81}$

("Most importantly, the top reply to a Trump tweet is guaranteed to get in front of hundreds of thousands of eyes.”).

${ }^{79}$ E.g., Donald J. Trump (@realDonaldTrump), TwITTER (Dec. 31, 2016, 5:17 AM), https://twitter.com/realDonaldTrump/status/815185071317676033?ref src=twsrc\%5Etfw\%7Ctwcamp\%5 Etweetembed\%7Ctwterm\%5E815185071317676033\&ref url=http\%3A\%2F\%2Ftime.com\%2F4758366 \%2Ftrump-most-popular-tweets-ever\%2F (garnering over 131,000 retweets, over 332,000 likes, and over 76,000 comments on his tweet wishing a happy new year "to my many enemies and those who have fought me and lost so badly they just don't know what to do").

${ }^{80}$ See Donald J. Trump (@realDonaldTrump), TwiTTER (July 26, 2017, 5:55 AM), https://twitter.com/realDonaldTrump/status/890193981585444864?ref_src=twsrc\%5Etfw\%7Ctwcamp\%5 Etweetembed\%7Ctwterm\%5E890193981585444864\&ref_url=https\%3A\%2F\%2Fwww.theatlantic.com\% 2Fpolitics\%2Farchive\%2F2017\%2F11\%2Fpricking-of-his-thumbs\%2F544547\%2F (retweeted over 39,600 times; liked over 119,110 times; and replied to over 25,000 times); Donald J. Trump (@realDonaldTrump), TwITTER (July 26, 2017, 6:04 AM), https://twitter.com/realDonaldTrump/status/890196164313833472?ref_src=twsrc\%5Etfw\%7Ctwcamp\%5 Etweetembed\%7Ctwterm\%5E890196164313833472\&ref_url=https\%3A\%2F\%2Fwww.theatlantic.com\% 2Fpolitics\%2Farchive\%2F2017\%2F11\%2Fpricking-of-his-thumbs\%2F544547\%2F (retweeted over 41,700 times; liked over 129,300 times; and replied to over 45,000 times); Donald J. Trump (@realDonaldTrump), TwITTER (July 26, 2017, 6:08 AM), https://twitter.com/realDonaldTrump/status/890197095151546369?ref src=twsrc\%5Etfw\%7Ctwcamp\%5 Etweetembed\%7Ctwterm\%5E890197095151546369\&ref url=https\%3A\%2F\%2Fwww.cnn.com\%2F201 7\%2F07\%2F26\%2Fpolitics\%2Ftrump-military-transgender\%2Findex.html (retweeted over 39,700 times; liked over 133,700 times; and replied to over 72,000 times).

${ }^{81}$ See e.g., Warzel, supra note X (describing the "race" of followers to reply to a Trump tweet because of the increase in followers those replying experience with their own Twitter accounts). 
Among the 53 million individuals who follow Trump on his @RDT Twitter account, several of them have responded to his tweets in a manner that was critical or questioning of the president. Several individuals who followed @RDT and who tweeted replies that were critical or questioning of the president or his policies were blocked from following his Twitter account shortly after they posted their critical questions or replies. ${ }^{82}$ One such individual, Joseph Papp, is a former professional road cyclist and current anti-doping advocate. ${ }^{83}$ Prior to being blocked, Mr. Papp was active in following and engaging with Trump's tweets on @RDT, posting replies that appeared in Trump's comment threads and were accessible by the millions who follow Trump on $@$ RDT. ${ }^{84}$ Mr. Papp's replies had also been quoted in media articles describing citizen responses to Trump. ${ }^{85}$ On June 3, 2017, President Trump tweeted a video of his weekly presidential address. ${ }^{86} \mathrm{~A}$ few minutes later, Mr. Papp replied to this tweet with a pair of linked tweets that said "Greetings from Pittsburgh, Sir," and "Why didn't you attend your \#PittsburghNotParis rally in DC, Sir?"17 The next day, on June 4, 2017, Mr. Papp learned that he had been blocked from following President Trump on his @RDT account. ${ }^{88}$

Another such individual who was blocked from following Trump on his @RDT account is Rebecca Buckwalter, a writer and political analyst whose articles have been published by

\footnotetext{
${ }^{82}$ See e.g., Ashley Feinberg, A Running List of People Donald Trump Has Blocked on Twitter, WIRED (June 14, 2017, 3:38 PM), https://www.wired.com/story/donald-trump-twitter-blocked (tracking the Twitter users blocked by Trump).

${ }^{83}$ See Complaint at 22, Knight First Amendment Inst. at Columbia Univ. v. Trump, 302 F. Supp. 3d 541 (S.D.N.Y. 2018) (No. 1:17 Civ. 05205).

${ }^{84}$ See Exhibit H to Joint Stipulation of Facts, Knight First Amendment Inst. at Columbia Univ. v. Trump, 302 F. Supp. 3d 541 (S.D.N.Y. 2018) (No. 1:17 Civ. 05205).

${ }^{85}$ See Complaint at 22, Knight First Amendment Inst. at Columbia Univ. v. Trump, 302 F. Supp. 3d 541 (S.D.N.Y. 2018) (No. 1:17 Civ. 05205).

${ }^{86}$ See Donald J. Trump (@realDonaldTrump), TwITTER (June 3, 2017, 12:53 PM), https://twitter.com/realDonaldTrump/status/871087981225926656.

${ }^{87}$ See Joe Papp (@joepabike), TwITTER (June 3, 2017, 12:36 PM), https://twitter.com/joepabike/status/871088288202928128; Joe Papp (@joepabike), TwITTER (June 3, 2017, 12:39 PM), https://twitter.com/joepabike/status/871089057098551296.

${ }^{88}$ See Complaint at 22, Knight First Amendment Inst. at Columbia Univ. v. Trump, 302 F. Supp. 3d 541 (S.D.N.Y. 2018) (No. 1:17 Civ. 05205).
} 
media outlets such as The Atlantic, National Public Radio, and CNN. ${ }^{89}$ Ms. Buckwalter had been active in following Trump on his @RDT account and frequently replying to Trump's tweets, such that her replies appeared in Trump's comment threads and were accessible by the millions who follow Trump on his @RDT account. ${ }^{90}$ On June 6, 2017, President Trump tweeted "Sorry folks, but if I would have relied on the Fake News of CNN, NBC, ABC, CBS washpost or nytimes, I would have had ZERO chance of winning WH." ${ }^{91}$ In response to this tweet, Buckwalter replied, "To be fair you didn't win the WH: Russia won it for you." ${ }^{92}$ Buckwalter's reply tweet in the @RDT comment thread, in turn, received over nine thousand likes and over three thousand retweets. ${ }^{93}$ Shortly thereafter, Buckwalter learned that she was blocked from the president's@RDT account. ${ }^{94}$

Brandon Neely was another avid follower of Trump on his @RDT account who engaged frequently with Trump and his followers via the @RDT account. ${ }^{95}$ Neely is a police officer and Iraq War Veteran with a Twitter account followed by approximately 10,200 people. ${ }^{96}$ When Neely replied to and commented on the president's tweets from @RDT, Neely's comments

${ }^{89}$ See Complaint at 17, Knight First Amendment Inst. at Columbia Univ. v. Trump, 302 F. Supp. 3d 541 (S.D.N.Y. 2018) (No. 1:17 Civ. 05205).

${ }^{90}$ See Exhibit C to Joint Stipulation of Facts, Knight First Amendment Inst. at Columbia Univ. v. Trump, 302 F. Supp. 3d 541 (S.D.N.Y. 2018) (No. 1:17 Civ. 05205).

${ }^{91}$ Donald J. Trump (@realDonaldTrump), TwITTER (June 6, 2017, 5:15 AM), https://twitter.com/realdonaldtrump/status/872064426568036353?lang=en.

92 RPBP (@rpbp), TwITTER (June 6, 2017, 5:16 AM), https://twitter.com/rpbp/status/8720647230843330.

93See RPBP (@rpbp), TwITTER (June 6, 2017, 5:16 AM), https://twitter.com/rpbp/status/8720647230843330.

${ }^{94}$ See Complaint at 17, Knight First Amendment Inst. at Columbia Univ. v. Trump, 302 F. Supp. 3d 541 (S.D.N.Y. 2018) (No. 1:17 Civ. 05205).

${ }^{95}$ See Exhibit G to Joint Stipulation of Facts, Knight First Amendment Inst. at Columbia Univ. v. Trump, 302 F. Supp. 3d 541 (S.D.N.Y. 2018) (No. 1:17 Civ. 05205) (listing tweets and replies from Brandon Neely's Twitter, @BrandonTXNeely).

${ }^{96}$ See Complaint at 21, Knight First Amendment Inst. at Columbia Univ. v. Trump, 302 F. Supp. $3 d 541$ (S.D.N.Y. 2018) (No. 1:17 Civ. 05205); Brandon Neely (@BrandonTXNeely), TwITTER, https://twitter.com/BrandonTXNeely?ref_src=twsrc\%5Egoogle\%7Ctwcamp\%5Eserp\%7Ctwgr\%5Eauthor 
frequently appeared at the top of the comment threads associated with @RDT. ${ }^{97}$ On June 12, 2017, President Trump tweeted "Congratulations! First new Coal Mine of Trump Era Opens in Pennsylvania," and included a link to a Fox News article about the mine's opening. ${ }^{98}$ In response to the president's tweet, Mr. Neely replied, "Congrats and now black lung won't be covered under \#TrumpCare."99 Mr. Neely's reply tweet drew a fair amount of attention, receiving 3,181 likes and 338 retweets. ${ }^{100}$ The next day, on June 13, 2017, Mr. Neely learned that he had been blocked from following the president on his @RDT account. Several other followers of Trump's @RDT Twitter account were blocked after making similar critical comments or posing critical questions to Trump as replies to his tweets. ${ }^{101}$

${ }^{97}$ See Complaint at 21, Knight First Amendment Inst. at Columbia Univ. v. Trump, 302 F. Supp. 3d 541 (S.D.N.Y. 2018) (No. 1:17 Civ. 05205).

${ }^{98}$ Donald J. Trump (@realDonaldTrump), TwITTER (June 12, 2017, 10:59 AM), https://twitter.com/realdonaldtrump/status/874325287143604224?lang=en.

99 Brandon Neely (@BrandonTXNeely), TwITTER (June 12, 2017, 11:00 AM), https://twitter.com/BrandonTXNeely/status/874325611334029313.

${ }_{100}$ See Brandon Neely (@BrandonTXNeely), TwITTER (June 12, 2017, 11:00 AM), https://twitter.com/BrandonTXNeely/status/874325611334029313.

${ }^{101}$ Four other individuals joined Buckwalter, Papp, and Neely, in a suit brought by the Knight First Amendment Institute at Columbia University, to challenge the president's act of blocking them from following his@RDT account, after these individuals were blocked for posting similar types of questions and comments in response to tweets from the president on his @RDT account. See Complaint at 3-4, Knight First Amendment Inst. at Columbia Univ. v. Trump, 302 F. Supp. 3d 541 (S.D.N.Y. 2018) (No. 1:17 Civ. 05205). Philip Cohen, a sociology professor at University of Maryland College Park and avid follower of the president's @RDT Twitter account, was blocked after posting a critical response to a Trump tweet. See Complaint at 18, Knight First Amendment Inst. at Columbia Univ. v. Trump, 302 F. Supp. 3d 541 (S.D.N.Y. 2018) (No. 1:17 Civ. 05205). See also Exhibit D to Joint Stipulation of Facts, Knight First Amendment Inst. at Columbia Univ. v. Trump, 302 F. Supp. 3d 541 (S.D.N.Y. 2018) (No. 1:17 Civ. 05205) (listing tweets and replies from Philip Cohen’s Twitter, @familyunequal). On June 6, 2017, Trump tweeted "\#ICYMI [In Case You Missed It] Announcement of Air Traffic Control Initiative...Watch," which provided a link to an announcement of an Air Traffic Control Initiative. Donald J. Trump (@realDonaldTrump), TwITTER (June 6, 2017, 5:44 PM), https://twitter.com/realdonaldtrump/status/872253002266161153?lang=en. Professor Cohen tweeted a reply showing a picture of the president with the words "Corrupt Incompetent Authoritarian. And then there are the policies. Resist." Philip N Cohen (@familyunequal), TwITTER (June 6, 2017, 5:45 PM), https://twitter.com/familyunequal/status/872253179915841536. Professor Cohen's reply tweet received over 300 likes and 35 retweets. See Complaint at 18, Knight First Amendment Inst. at Columbia Univ. v. Trump, 302 F. Supp. 3d 541 (S.D.N.Y. 2018) (No. 1:17 Civ. 05205). Shortly after Professor Cohen tweeted his reply, he was blocked from following the president on his @RDT account. See Complaint at 18, Knight First Amendment Inst. at Columbia Univ. v. Trump, 302 F. Supp. 3d 541 (S.D.N.Y. 2018) 
(No. 1:17 Civ. 05205). Holly Figueroa, a national political organizer and songwriter, was an avid follower of the president on his @RDT account. See Complaint at 19 Knight First Amendment Inst. at Columbia Univ. v. Trump, 302 F. Supp. 3d 541 (S.D.N.Y. 2018) (No. 1:17 Civ. 05205). See also Exhibit E to Joint Stipulation of Facts, Knight First Amendment Inst. at Columbia Univ. v. Trump, 302 F. Supp. 3d 541 (S.D.N.Y. 2018) (No. 1:17 Civ. 05205) (listing tweets and replies from Holly Figueroa's Twitter, @AynRandPaulRyan). Many of her replies to the president's tweets garnered thousands of responses in the form of likes and retweets and appeared at or near the top of the president's comment threads. See Complaint at 19, Knight First Amendment Inst. at Columbia Univ. v. Trump, 302 F. Supp. 3d 541 (S.D.N.Y. 2018) (No. 1:17 Civ. 05205). On May 28, 2017, the president addressed the terrorist attack in Manchester, England, by tweeting "British Prime Minister May was very angry that the info the U.K. gave to the U.S. about Manchester was leaked. Gave me full details!” Donald J. Trump (@realDonaldTrump), TwITTER (May 28, 2017, 7:43 AM), https://twitter.com/realdonaldtrump/status/868840252227674113?lang=en. In response to the president's tweet, Ms. Figueroa replied with a tweet (which in turn received 15,000 likes) containing a picture of the Pope looking incredulously at the president, along with the tweet "This is pretty much how the whole world sees you.” Holly Figueroa O'Reilly BWCS (@AynRyanPaulRyan), TwITTER (May 28, 2017, 7:53 $\mathrm{AM})$, https://twitter.com/AynRandPaulRyan/status/868842669069422592?ref_src=twsrc\%5Etfw\%7Ctwcamp\% 5Etweetembed\%7Ctwterm\%5E868842669069422592\&ref url=https\%3A\%2F\%2Fwww.cnbc.com\%2F2 018\%2F05\%2F23\%2Fread-the-tweets-that-got-these-people-blocked-on-twitter-by-president-donaldtrump.html. Hours later, Ms. Figueroa learned that she was blocked from following the president on his @RDT Twitter account. See Complaint at 19, Knight First Amendment Inst. at Columbia Univ. v. Trump, 302 F. Supp. 3d 541 (S.D.N.Y. 2018) (No. 1:17 Civ. 05205). Eugene Gu, a resident in general surgery, was an avid follower of the president’s @RDT Twitter account, with some of his replies to @realDonaldTrump receiving thousands of likes and appearing on “Twitter Moments” (Twitter's encapsulation of current events that incorporate particularly popular tweets). See Complaint at 20, Knight First Amendment Inst. at Columbia Univ. v. Trump, 302 F. Supp. 3d 541 (S.D.N.Y. 2018) (No. 1:17 Civ. 05205). See also source Exhibit F to Joint Stipulation of Facts, Knight First Amendment Inst. at Columbia Univ. v. Trump, 302 F. Supp. 3d 541 (S.D.N.Y. 2018) (No. 1:17 Civ. 05205) (listing tweets and replies from Eugene Gu’s Twitter, @eugenegu). On June 28, 2017 at 4:02 am, the president tweeted “The new Rasmussen Poll, one of the most accurate in the 2016 Election, just out with a Trump 50\% Approval Rating. That's higher than O’s \#’s!” Donald J. Trump (@realDonaldTrump), TwITTER (June 18, 2017, 4:02 AM), https://twitter.com/realdonaldtrump/status/876394578777174021?lang=en. In response to the president's tweet, Mr. Gu replied “Covfefe: The same guy who doesn’t proofread his Twitter handles the nuclear button" (in which Mr. Gu referred to the president's unexplained tweet from May 31, 2017, which read in full: “Despite the constant negative press covfefe.”) Eugene Gu, MD (@eugenegu), TwITTER (June 18, 2017, 4:12 AM), https://twitter.com/eugenegu/status/876397178780078081. See also Matt Flegenheimer, What's a 'Covfefe'? Trump Tweet Unites a Bewildered Nation, N.Y. TIMES (May 31, 2017), https://www.nytimes.com/2017/05/31/us/politics/covfefe-trump-twitter.html. Mr. Gu’s reply tweet received 2,900 likes and 239 retweets. See Eugene Gu, MD (@eugenegu), TwITTER (June 18, 2017, 4:12 AM), https://twitter.com/eugenegu/status/876397178780078081. Shortly thereafter, Mr. Gu learned that he had been blocked from following the president on his @RDT Twitter account. See Complaint at 20, Knight First Amendment Inst. at Columbia Univ. v. Trump, 302 F. Supp. 3d 541 (S.D.N.Y. 2018) (No. 1:17 Civ. 05205). Nick Pappas, a comic and writer, was an avid follower of the president's @RDT Twitter account, and his replies to the president often received thousands of likes and retweets. See Complaint at 22, Knight First Amendment Inst. at Columbia Univ. v. Trump, 302 F. Supp. 3d 541 (S.D.N.Y. 2018) (No. 1:17 Civ. 05205). See also Exhibit I to Joint Stipulation of Facts, Knight First Amendment Inst. at Columbia Univ. v. Trump, 302 F. Supp. 3d 541 (S.D.N.Y. 2018) (No. 1:17 Civ. 05205) (listing tweets and replies from Nick Pappas's Twitter, @Pappiness). On June 5, 2017, the president tweeted “The Justice Dept. should ask for an expedited hearing of the watered down Travel Ban 
As a result of being blocked from following Trump's @RDT account, these blocked individuals were no longer able to interact or engage with the president's tweets on his extensive Twitter platform or to participate and engage in the wide-ranging policy discussions that the president's tweets engender. ${ }^{102}$ Specifically, individuals blocked from following the president's @RDT Twitter account cannot view tweets from @RDT on the Twitter platform, cannot reply to these tweets, and cannot reply to replies on these tweets. ${ }^{103}$ In addition, the blocked individuals' tweets replying to the president's tweets are not viewable by the millions of Americans who follow the president on his @RDT account. ${ }^{104}$ As such, blocked individuals are prohibited from meaningfully engaging and interacting with the president's tweets on his Twitter platform of choice, which is his chosen and preferred means of engaging with his constituents, the American people. ${ }^{105}$

before the Supreme Court - \& seek much tougher version!" and "In any event we are EXTREME VETTING people coming into the U.S. in order to keep our country safe. The courts are slow and political!” Donald J. Trump (@realDonaldTrump), TwITTER (June 5, 2017, 3:37 AM), https://twitter.com/realdonaldtrump/status/871677472202477568?lang=en; Donald J. Trump (@realDonaldTrump), TWITTER (June 5, 2017, 3:44 AM), https://twitter.com/realdonaldtrump/status/871679061847879682?lang=en. In response to the president's tweets, Mr. Pappas replied, "Trump is right. The government should protect the people. That's why the courts are protecting us from him.” Nick Jack Pappas (@Pappiness), TwITTER (June 5, 2017, 3:50 AM), https://twitter.com/Pappiness/status/871680720707747840. This tweet received 395 retweets and 1,181 likes. See Complaint at 23, Knight First Amendment Inst. at Columbia Univ. v. Trump, 302 F. Supp. 3d 541 (S.D.N.Y. 2018) (No. 1:17 Civ. 05205). Within a few hours of replying to the president, Mr. Pappas learned that he was blocked from following the president on his @RDT Twitter account. See Complaint at 23, Knight First Amendment Inst. at Columbia Univ. v. Trump, 302 F. Supp. 3d 541 (S.D.N.Y. 2018) (No. 1:17 Civ. 05205).

${ }^{102}$ See How to Block Accounts on Twitter, TWITTER HELP CENTER, https://help.twitter.com/en/usingtwitter/blocking-and-unblocking-accounts (last visited July 15, 2018) (listing the actions that a blocked account cannot take).

${ }^{103}$ See Cross-Motion of Plaintiff for Summary Judgment and Opposition to Defendant's Motion for Summary Judgment at 14, Knight First Amendment Inst. at Columbia Univ. v. Trump, 302 F. Supp. 3d 541 (S.D.N.Y. 2018) (No. 1:17 Civ. 05205).

${ }^{104}$ See How to Block Accounts on Twitter, TWITTER HELP CENTER, https://help.twitter.com/en/usingtwitter/blocking-and-unblocking-accounts (last visited July 15, 2018) (advising users that "[t]weets from blocked accounts will not appear in your timeline").

${ }^{105}$ See e.g., Nicholas Carr, Why Trump Tweets (And Why We Listen), Politico (Jan. 26, 2018), https://www.politico.com/magazine/story/2018/01/26/donald-trump-twitter-addiction-216530 (analyzing Trump’s “fixation” with Twitter). 


\section{Lawsuits Challenging Government Officials' Blocking of Users from Social Media Forums}

In each of the cases described above, citizens who were blocked by government officials from engaging with them on the officials' social media forums brought suit, claiming that their First Amendment rights had been violated. The Maryland citizens claimed, in their suit against Governor Hogan, that the comment space on Governor Hogan's Facebook page constituted a public forum for speech and that the Social Media Policy under which Hogan blocked citizens who questioned or criticized his policies constituted illegal viewpoint discrimination within a public forum. ${ }^{106}$ Similarly, Virginia citizen Brian Davison claimed, in his suit against the Loudoun County Board of Supervisors, that the comment space on Commissioner Randall's Facebook page constituted a public forum for speech and that the blocking of Davison based on his critical comments about Randall constituted illegal viewpoint discrimination within that public forum. ${ }^{107}$ And the seven Twitter users who were blocked from accessing President Trump's @RDT Twitter account also claimed that the interactive space on Trump's account constituted a public forum from which they were unconstitutionally blocked based on their viewpoints. ${ }^{108}$ In each case, the government officials responded by asserting that the forums at issue were not properly considered public forums under the First Amendment public forum doctrine. ${ }^{109}$ Instead, they assert that they were operating these accounts in their personal capacity

\footnotetext{
${ }^{106}$ See Complaint at 3, Laurenson et al. v. Hogan, No. 8:17 Civ. 02162-DKC (filed on Aug. 1, 2017) (alleging that Governor Hogan, through the social media policy "engag[ed] in unconstitutional viewpoint discrimination to remove certain ideas or perspectives from a broader public debate").

${ }^{107}$ See Complaint at 7, Davison v. Loudoun Cnty. Bd. of Supervisors, 267 F. Supp. 3d 702 (E.D. Va. May 10, 2017).

${ }^{108}$ See Complaint at 2-3, Knight First Amendment Inst. at Columbia Univ. v. Trump, 302 F. Supp. 3d 541 (S.D.N.Y. 2018) (No. 1:17 Civ. 05205)..

${ }^{109}$ See Hogan Answer; Defendants Loudoun County Board of Supervisors and Phyllis Randall's Memorandum In Support of Motion For Summary Judgment Filed Pursuant to Fed. R. Civ. P. 56(a) at 14, Davison v. Loudoun Cnty. Bd. of Supervisors, 267 F. Supp. 3d 702, (E.D. Va. 2017) (No. 1:16 Civ. 00932); Motion of Government for Summary Judgment at 11, Knight First Amendment Inst. at Columbia Univ. v. Trump, 302 F. Supp. 3d 541 (S.D.N.Y. 2018) (No. 1:17 Civ. 05205).
} 
not in their official government capacity, and that they therefore enjoy the First Amendment right to delete comments and/or block individuals from these forums. ${ }^{110}$ In the alternative, they argue that if these sites are viewed as governmental, their speech constitutes "government speech," which is immune from scrutiny under the Free Speech Clause. ${ }^{111}$ Before analyzing these cases in greater detail, below I examine the historical development, evolution, and importance of the public forum doctrine in American First Amendment jurisprudence, as well as the recently developed government speech doctrine, under which government expression is immune from scrutiny under the First Amendment's Free Speech Clause.

\section{The Development and Evolution of the Public Forum Doctrine}

\section{A. Introduction}

The public forum doctrine mandates that the government facilitate speech by requiring that certain forums be made or held available for uncensored discussion, debate, and exercise of other First Amendment freedoms. ${ }^{112}$ This doctrine, which grows out of the 1939 case of Hague v. CIO, ${ }^{113}$ imposes obligations on the government to facilitate speech without discrimination on the basis of viewpoint within places that are traditionally devoted to or are well-suited to the exercise of such freedoms -- such as public parks, sidewalks and streets -- as well as within

\footnotetext{
${ }^{110}$ See Hogan Answer; Defendants Loudoun County Board of Supervisors and Phyllis Randall's Memorandum In Support of Motion For Summary Judgment Filed Pursuant to Fed. R. Civ. P. 56(a) at 14, Davison v. Loudoun Cnty. Bd. of Supervisors, 267 F. Supp. 3d 702, (E.D. Va. 2017) (No. 1:16 Civ. 00932) (challenging the assertion that Randall's Facebook page is a public forum because it "was created and controlled by her personally and is not subject to control or administration by the County or subject $\mathrm{t}$ its social media policy”); Motion of Government for Summary Judgment at 11, Knight First Amendment Inst. at Columbia Univ. v. Trump, 302 F. Supp. 3d 541 (S.D.N.Y. 2018) (No. 1:17 Civ. 05205) (classifying Trump's Twitter use as an official's "routine[] engage[ment] in personal conduct that is not an exercise of state power").

${ }^{111}$ See Hogan Answer; Motion of Government for Summary Judgment at 15, Knight First Amendment Inst. at Columbia Univ. v. Trump, 302 F. Supp. 3d 541 (S.D.N.Y. 2018) (No. 1:17 Civ. 05205).

${ }^{112}$ See e.g., Perry Educ. Ass'n v. Perry Local Educators' Ass'n, 460 U.S. 37, 45 (1983) ("In places which by long tradition or by government fiat have been devoted to assembly and debate, the rights of the State to limit expressive activity are sharply circumscribed.”).

${ }^{113}$ Hague v. CIO, 307 U.S. 494 (1939).
} 
places that the government has chosen to open up for expressive purposes, whether those places are government-owned or privately-owned but government-controlled. ${ }^{114}$

Since the Supreme Court's adoption of the public forum doctrine in the mid-twentieth century, the state and "state actors"115 have been constitutionally required to facilitate and to refrain from suppressing speech on the basis of viewpoint within such forums. ${ }^{116}$ Under the public forum doctrine, the government is held to exacting standards regarding its ability to restrict speech within such forums. ${ }^{117}$ The existence of public forums like public sidewalks, streets, and parks advances free speech values by providing forums for individuals to communicate with and reach out to broad general audiences as well as to particularly relevant specific audiences. ${ }^{118}$ The Supreme Court has recognized that the availability of such forums in which individuals are ensured the meaningful right and opportunity to express themselves has been central to freedom of expression and to democratic self-government "from time immemorial." 119 Because of the important function that such public places serve in facilitating the exchange of ideas and expression in democracies, the public forum doctrine imposes upon the government the obligation to preserve and protect such places for free expression. ${ }^{120}$

\footnotetext{
${ }^{114}$ See, e.g., Packingham, 137 S. Ct at 1735 ("A basic rule, for example, is that a street or park is a quintessential forum for the exercise of First Amendment rights); source 66 at 555 (holding a private theater leased by the government as a public forum).

${ }^{115}$ See text accompanying notes $\mathrm{x}-\mathrm{y}$.

${ }^{116}$ See Rosenberger v. Rector Visitors of the Univ. of Va., 515 U.S. 819, 829 (1995) (explaining that the State is forbidden from "exercising viewpoint discrimination, even when the limited public forum is one of its own creation”).

117 See Rosenberger, 515 U.S. at 829 ("The government must abstain from regulating speech when the specific motivating ideology or the opinion or perspective of the speaker is the rationale for the restriction.”).

${ }^{118}$ See Hague, 307 U.S. at 515.

${ }^{119}$ See Hague, 307 U.S. at 513 (protecting the right to peaceably petition the government as "an attribute of national citizenship").

${ }^{120}$ See Packingham, 137 S. Ct at 1735 (identifying public forums as "essential venues for public gatherings to celebrate some views, to protest others, or simply to learn and inquire”).
} 
The Supreme Court championed the values served by the public forum in what is known as its first public forum case, Hague v. CIO. ${ }^{121}$ This case arose out of a dispute between members of the Committee for Industrial Organization (now part of the AFL-CIO) and Jersey City, New Jersey, which was hostile to the message that the CIO sought to communicate. ${ }^{122}$ Members of the CIO sought to conduct informational outreach in various public venues in Jersey City to explain to City workers the purposes and benefits of the National Labor Relations Act and to distribute pamphlets on the subject. ${ }^{123} \mathrm{CIO}$ members repeatedly sought from the City -- and were repeatedly denied -- permission to lease the city hall to conduct public meetings and/or distribute their pamphlets in city streets and other similar public places. ${ }^{124}$ When CIO members continued attempting to express their message in these public places, the mayor ordered them arrested and literally ferried out of the City on boats bound for New York. ${ }^{125}$

In response to the CIO's claim that the City violated its First Amendment rights, the City argued that its right to exclude people from City property was as absolute as that of a private property owner to exclude people from his or her home, and that the City therefore enjoyed the power to exclude whichever citizens it chose for whatever reasons it chose from City property. ${ }^{126}$ The CIO contended that the City was chargeable with different duties than those of a private owner of property - duties to facilitate the expression of members of the public on matters of public importance. ${ }^{127}$ The Supreme Court agreed. ${ }^{128}$ In ushering in the modern public forum doctrine, the Court explained that the existence and flourishing of our form of democratic self-

\footnotetext{
121307 U.S. 496 (1939).

${ }^{122}$ See Hague, 307 U.S. at 501.

${ }^{123}$ See Hague, 307 U.S. at 501-02.

${ }^{124}$ See Hague, 307 U.S. at 502-03.

${ }^{125}$ See Hague, 307 U.S. at 502.

${ }^{126}$ See Hague, 307 U.S. at 514.

${ }^{127}$ See Hague, 307 U.S. at 514-16.

${ }^{128}$ See Hague, 307 U.S. at 514-16.
} 
government require that citizens enjoy meaningful opportunities to express themselves and meaningful venues in which to do so:

The very idea of a government, republican in form, implies a right on the part of its citizens to meet peaceably for consultation in respect to public affairs and to petition for a redress of grievances. . . . Citizenship of the United States would be little better than a name if it did not carry with it the right to discuss national legislation and the benefits, advantages, and opportunities to accrue to citizens therefrom. ${ }^{129}$

The Court rejected Jersey City’s claim that its right to exclude was as absolute as that of a private property owner and adopted what is now known as the public forum doctrine, in which the government is charged with the obligation to facilitate speech without discrimination on certain types of property:

Wherever the title of streets and parks may rest, they have immemorially been held in trust for the use of the public, and time out of mind, have been used for purposes of assembly, communicating thoughts between citizens, and discussing public questions. Such use of the streets and public places has, from ancient times, been a part of the privileges, immunities, rights, and liberties of citizens. The privilege of a citizen of the United States to use the streets and parks for communication of views on national questions . . . must not, in the guise of regulation, be abridged or denied. ${ }^{130}$

Accordingly, in Hague v. CIO, the Court imposed on government actors the obligation not to discriminate against, and to accord the widest possible latitude to, speech within property like streets and parks that has "immemorially been held in trust for the use of the public ... for purposes of assembly, communicating thought between citizens, and discussing public questions." 131 Within these "traditional public forums," individuals are guaranteed not just the right in theory but also the meaningful opportunity in practice to express themselves.

Eight months after the Hague decision, the Supreme Court solidified its newly-articulated

\footnotetext{
${ }^{129}$ See Hague, 307 U.S. at 513 (internal quotations omitted).

${ }^{130}$ See Hague, 307 U.S. at 515-16.

${ }^{131}$ See Hague, 307 U.S. at 515.
} 
public forum doctrine in the case of Schneider v. State. ${ }^{132}$ In Schneider, individuals who had handed out leaflets on a public street announcing a protest were convicted of violating an ordinance prohibiting the distribution of leaflets on public streets. ${ }^{133}$ The municipality defended the ordinance on the grounds that it was designed to prevent littering and that there were other venues available to the speakers to disseminate their message. ${ }^{134}$ Rejecting the municipality's argument, the Court explained that the government has an obligation to facilitate speech within places that are well-suited to such expression. ${ }^{135}$ Justice Roberts wrote:

The streets are natural and proper places for the dissemination of information and opinion; and one is not to have the exercise of his liberty of expression in appropriate places abridged on the plea that it may be exercised in some other place. ${ }^{136}$

In both Hague and Schneider, the Supreme Court underscored the importance that the unrestricted, uncensored free flow of information serves in our system of democratic selfgovernment. Because the right to engage in such speech is "so vital to the maintenance of democratic institutions" and is implied within "the very idea of government, republic in form," the government is not permitted to restrict the exercise of free speech on such property. ${ }^{137}$

Not all public property enjoys public forum status, however. Property such as government-owned office buildings, state prisons, and places that are not held open by the government or traditionally used for expressive purposes are not considered public forums in

\footnotetext{
132308 U.S. 147, 160 (1939).

${ }^{133}$ See Schneider, 308 U.S at 155.

${ }^{134}$ See Schneider, 308 U.S at 155-56.

${ }^{135}$ See Schneider, 308 U.S at 160 ("Municipal authorities, as trustees for the public, have the duty to keep their communities' streets open and available for movement of people and property, the primary purpose to which the streets are dedicated.”).

${ }^{136}$ Schneider, 308 U.S. at 160 (emphasis added).

${ }^{137}$ Schneider, 308 U.S. at 161; Hague, 307 U.S. at 513.
} 
which the state is obligated to facilitate citizens' free speech rights. ${ }^{138}$ But, within governmentowned property that has traditionally been available for expressive purposes -- like public parks, streets, sidewalks -- or property that the government has made available for expressive purposes, all speakers are permitted to express themselves. ${ }^{139}$ It is within these public forums that citizens enjoy the fullest and most meaningful protection of their right to free expression. ${ }^{140}$ The government is required to permit speech within such forums ${ }^{141}$ - regardless of the content of such speech or the viewpoint of the speaker - and any restrictions on speech within such forums are subject to the strictest judicial scrutiny. ${ }^{142}$ The mandate that the government preserve forums for the nondiscriminatory exercise of the right of free speech provides a crucial safeguard for free expression. Speakers can enter traditional public forums like public parks, streets, and sidewalks, and express themselves with the assurance that their speech cannot be censored by the forum owner on the basis of viewpoint or subject matter. ${ }^{143}$

After its initial inception in the mid-twentieth century, the development of the public forum doctrine became more complex. Recent Supreme Court cases have broken out public forums into the following categories ${ }^{144}$ : (1) traditional public forums; (2) designated public

\footnotetext{
${ }^{138}$ In particular, authoritarian government forums, like prisons, military bases, and schools, are generally considered non-public forums. See, e.g., Adderley v. Florida, 385 U.S. 39, 41 (1966) (county jail not a public forum); Greer v. Spock, 424 U.S. 828, 838 (1976) (military base not a public forum).

${ }^{139}$ See Perry Educ. Ass'n, 460 U.S. at 45 (recognizing traditional public fora as "places which by long tradition or by government fiat have been devoted to assembly and debate"). As I explain infra, within a designated public forum devoted to particular subjects, however, the government may impose restrictions limiting expression to the particular subject matter(s) for which the forum is designated. See text accompanying notes $\mathrm{x}-\mathrm{y}$.

${ }^{140}$ See Perry Educ. Ass'n, 460 U.S. at 45 (describing the State's right to limit expressive activity in traditional public fora as "sharply circumscribed").

${ }^{141}$ See Perry Educ. Ass'n, 460 U.S. at 45 (1983).

${ }^{142}$ See, e.g., Burson v. Freeman, 504 U.S. 191, 198 (1992) (requiring "exacting scrutiny" for "facially content-based restriction[s] on political speech in a public forum").

${ }^{143}$ See Perry Educ. Ass'n, 460 U.S. at 45 (prohibiting states from "prohibit[ing] all communicative activity").

${ }^{144}$ In Perry, the Court provided an especially clear overview of its recent public forum jurisprudence, explaining:
} 
forums (both of general purpose and limited purpose); and (3) nonpublic forums. ${ }^{145}$

“Traditional” public forums consist of streets, sidewalks, and parks and other places that "have immemorially been held in trust for the use of the public, and, time out of mind, have been used for purposes of assembly, communicating thoughts between citizens, and discerning public questions." 146 The Court has recently made clear that this category is limited to streets, sidewalks, and parks and will not readily be expanded. ${ }^{147}$ "Designated public forums” consist of government-owned or government-controlled property that has not "immemorially" been used

At one end of the spectrum are streets and parks, which have immemorially been held in trust for the use of the public and, time out of mind, have been used for purposes of assembly, communicating thoughts between citizens, and discussing public questions.... In these [traditional public forums or] quintessential public forums, the government may not prohibit all communicative activity. For the State to enforce a content-based exclusion, it must show that its regulation is necessary to serve a compelling state interest and that it is narrowly drawn to achieve that end. ... The State may also enforce regulations of the time, place, and manner of expression which are content-neutral, are narrowly tailored to serve a significant government interest, and leave open ample alternative channels of communication. ... A second category [designated public forums] consists of public property which the State has opened for use by the public as a place for expressive activity. The Constitution forbids a State to enforce certain exclusions from a forum generally open to the public even if it was not required to create the forum in the first place. Although a State is not required to indefinitely retain the open character of the facility, as long as it does so, it is bound by the same standards as apply in a traditional public forum. Reasonable time, place, and manner regulations are permissible, and a contentbased prohibition must be narrowly drawn to effectuate a compelling state interest.... Public property which is not, by tradition or designation, a forum for public communication [nonpublic forums] is governed by different standards. ... In addition to time, place, and manner regulations, the State may reserve the forum for its intended purposes, communicative or otherwise, as long as the regulation on speech is reasonable and not an effort to suppress expression merely because public officials oppose the speaker's view. Perry Educ. Ass'n, 460 U.S. at 45-46.

145 The category of nonpublic forums includes places like military bases, jail grounds, and federal workplaces, that the government owns but which it has not opened up for expressive activity on the part of the public. See e.g., Perry Educ. Ass'n, 460 U.S. at 46-47 (classifying a school mail facility as a nonpublic forum).

${ }^{146}$ Hague, 307 U.S. at 515.

${ }^{147}$ See, e.g., Arkansas Ed. Television Comm’n v. Forbes, 523 U. S. 666 , 679 (1998) (explaining that "[t]he Court has rejected the view that traditional public forum status extends beyond its historic confines.”) Recent cases have also made clear that not all expressive activity within a public street, sidewalk, or park will be treated the same under the public forum doctrine. See, e.g., Pleasant Grove City v. Summum, 555 U.S. 460 (2009), discussed infra. Rather, the Court will consider the nature and the type of access sought within the forum at issue. See text accompanying notes $\mathrm{x}-\mathrm{y}$. 
for expressive purposes but which the government has opened up and designated as a place for public expressive activity. ${ }^{148}$ The government may choose, for example, to open up property within a public school, ${ }^{149}$ public university meeting facilities, ${ }^{150}$ or privately-owned municipal theaters leased by the government ${ }^{151}$ as forums for expression generally or for expression on certain designated subjects. Within a general-purpose designated public forum, the government is prohibited from discriminating on the basis of the content, subject matter, or viewpoint of the speech at issue. ${ }^{152}$ Within a limited-purpose designated public forum (also known as a "limited public forum”), once the government has defined the subject matter limitations of the forum (for example, by limiting the forum to speech on social, civic, and recreational topics ${ }^{153}$ ), the government may restrict the forum to speech that concerns those subjects, but beyond such permissible subject-matter restrictions, regulation is subject to the same stringent limitations as those governing a traditional public forum, and viewpoint discrimination is strictly prohibited. ${ }^{154}$

${ }^{148}$ See Perry Educ. Ass'n, 460 U.S. at 45 (1983)

${ }^{149}$ See City of Madison Joint School Dist. v. Wisc. Employment Relations Comm'n, 429 U.S. 167, 176 (1976) ("[W]hen the [school] board sits in public meetings to conduct public business and hear the views of citizens, it may not be required to discriminate between speakers on the basis of their employment, or the content of their speech.”).

${ }^{150}$ See Widmar v. Vincent, 454 U.S. 263, 267 (1981) ("Through its policy of accommodating their meetings, the University has created a forum generally open for use by student groups. Having done so, the University has assumed an obligation to justify its discriminations and exclusions under applicable constitutional norms.”).

151 See Southeastern Promotions Ltd. v. Conrad, 420 U.S. 546, 555 (1975) (concluding that the auditoriums at issue "were public forums designed for and dedicated to expressive activities").

${ }^{152}$ See Perry Educ. Ass'n, 460 U.S. at 46 (requiring states that choose to indefinitely retain the open character of the facility to do so "by the same standards as apply in a traditional public forum").

${ }^{153}$ See, e.g., Lamb's Chapel v. Ctr. Moriches Union Free Sch. Dist., 508 U.S. 384, 387 (1993) (school district restricted the use of school property after school hours to social, civic, and recreational uses of such property).

${ }^{154}$ See Int'l Soc'y for Krishna Consciousness, 505 U.S. 672, 678 (1992) (describing the regulation of designated public forums as "subject to the same limitations as that governing a traditional public forum"). Members of the Court have had a difficult time agreeing upon what constitutes a permissible subject matter or content restriction within a limited public forum and what constitutes an impermissible viewpoint restriction within limited public forums. In Rosenberger v. Rector \& Visitors of University of Virginia, for example, the forum at issue was the University's funding scheme for student publications, which authorized payment from the Student Activities Fund for the costs of printing of student 
Thus, within traditional public forums such as streets, sidewalks, and parks, and within designated public forums such as public meeting places devoted to expression on particular subjects, individuals enjoy their most robust rights of free expression. Government restrictions on speech within both types of public forums are subject to the most stringent scrutiny. Speech restrictions will not be upheld unless they serve compelling government interests and are the least restrictive means of restricting such speech. Content-based discrimination is generally prohibited, ${ }^{155}$ and viewpoint-based discrimination is absolutely prohibited, within such forums.

In circumstances where it is unclear whether the government has designated a public forum by opening up a nontraditional forum for public discourse, courts will look predominantly to two factors: (1) the policy and practice of the government or the government official with respect to its use of the property; (2) the nature of the property at issue and the compatibility of the property with expressive activity. ${ }^{156}$ Although the government will frequently have the incentive to argue that it did not open up the property at issue at all, or for the type of speech that

publications but prohibited payment from the Fund for the costs of printing for any publication that "primarily promotes or manifests a particular belief in or about a deity or an ultimate reality." 515 U.S. 819, 836 (1995). The student publication "Wide Awake: A Christian Perspective At the University of Virginia," which published a journal that offered a "Christian perspective" on issues such as racism, crisis pregnancy, homosexuality, and eating disorders, was denied funding under this scheme, and sued. See id. at 826-27. The Justices agreed that the funding scheme constituted a limited public forum for private speech, but disagreed as to whether limiting funding only to those student publications that did not "primarily promote or manifest a particular belief in or about a deity or an ultimate reality" constituted a subject matter/topic restriction or a viewpoint restriction. Id. at 836. In the Opinion of the Court, Justice Kennedy explained that this restriction amounted to viewpoint discrimination, because it was the religious perspective of the journal, rather than the subjects discussed, that triggered the university's refusal to pay for the printing costs of the journal. See id. 68 at 834. In his dissent, Justice Souter construed the restriction as a permissible subject matter restriction of denying funding for "the entire subject matter of religious apologetics," not an impermissible restriction on the basis of viewpoint and concluded that if the policy at issue in the case "amounts to viewpoint discrimination, the Court has all but eviscerated the line between viewpoint and content.” Id. at 896-98 (Souter, J., dissenting).

${ }^{155}$ Restrictions based on content or topic are only permitted only where necessary to confine the limited purpose designated public forum to the limited purposes for which it was created. See, e.g., Rosenberger, 515 U.S. at (explaining that "the necessities of confining a forum to the limited and legitimate purposes for which it was created may justify the State in reserving it for ... the discussion of certain topics. ...”). ${ }^{156}$ See Cornelius v. NAACP Legal Defense \& Education Fund, Inc., 473 U.S. 788, 802. 
the petitioner seeks to engage in, courts generally will look not just to the government's claims on this issue but to objective factors surrounding the policy and practice of the government, the nature of the property, and its compatibility with expressive activity.

For example, in the case of City of Madison, Joint School District \#8 v. Wisconsin Employment Relations Commission, the School Board and the City of Madison, Wisconsin, maintained that they had opened up a public forum that was limited in scope and that they were justified in limiting petitioner's speech on the grounds that it was outside that limited scope. ${ }^{157}$ The Court held that, once a meeting of the Board of Education had been made open to the public, the Board could not discriminate against speakers on the basis of their viewpoint. ${ }^{158}$ In that case, the school board and the City of Madison had convened a public meeting with a broad agenda (which included employment matters) and invited all members of the public to attend. ${ }^{159}$ During the meeting, the Board sought to silence the speech of an individual who intended to speak on collective bargaining matters. ${ }^{160}$ While recognizing that the School Board was entitled to conduct private meetings that were not open to the public and to limit the agenda of its meetings, the Court explained that, once the Board opened up its meetings to the public for direct citizen involvement and sat to conduct public business and hear the views of its citizens, it could not silence a speaker "seeking to express his views on an important decision of the government," nor could it discriminate among speakers on the basis of the viewpoint or content of their speech or the nature of their employment. ${ }^{161}$ The Court observed that "to permit one side of a debatable public question to have a monopoly in expressing its views to the government is the antithesis of

\footnotetext{
157429 U.S. 167, 172 (1976)

158 See Madison Joint Sch. Dist., 429 U.S. at 175.

${ }^{159}$ See Madison Joint Sch. Dist., 429 U.S. at 171.

${ }^{160}$ See Madison Joint Sch. Dist., 429 U.S. at 173.

${ }^{161}$ Madison Joint Sch. Dist., 429 U.S. at 175.
} 


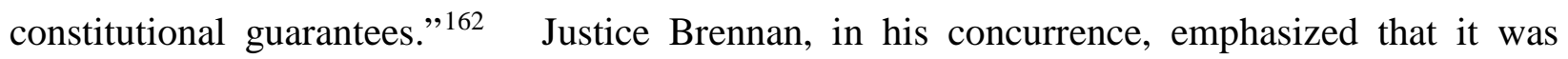
constitutionally impermissible for the government to allow for selective exclusions from public forums it had opened up, explaining that, in the case at bar, "the state body has created a public forum dedicated to the expression of views by the general public" and that "once a forum is opened up to assembly or speaking by some groups, government may not prohibit others from assembling or speaking on the basis of what they intend to say.”163

Similarly, in the case of Widmar v. Vincent, the government sought to maintain that it had opened up a public forum of a limited scope, not including religious purposes, but the Court held that objective factors supported the conclusion that the forum was not so limited. ${ }^{164}$ In that case, the University of Missouri at Kansas City had adopted the policy and practice of making its meeting facilities generally available to all registered student groups, but sought to limit the facilities' use to non-religious purposes and discussions. ${ }^{165}$ The Court found that the University's policy evidenced a clear intent to create a public forum for use by all registered student groups, and therefore held that the university could not withhold access from student groups and speakers based on the desire to use this generally open forum to engage in religious discussion. ${ }^{166}$

The Supreme Court has also emphasized that, in evaluating a petitioner's First Amendment claims under the public forum doctrine, the court must look not just to the property at issue but to the nature of the access sought by the petitioner. For example, in Cornelius $v$. NAACP Legal Defense and Education Fund, Inc., the NAACP challenged its exclusion from the

\footnotetext{
162 Madison Joint Sch. Dist., 429 U.S. at 175-76.

163 Madison Joint Sch. Dist., 429 U.S. at 179.

${ }^{164}$ Widmar v. Vincent, 454 U.S. 263, 277 (1981)

165 See Widmar, 454 U.S. at 265.

166 See Widmar, 454 U.S. at 277.
} 
Combined Federal Campaign, an annual charitable fund-raising drive conducted through the federal workplace during work hours through the voluntary efforts of public employees. ${ }^{167}$ In evaluating the NAACP's claims, the Court emphasized that the access the Fund sought was not to the federal workplace itself, but rather to participation as one of the choices in the fund-raising drive established by the Combined Federal Campaign. ${ }^{168}$ In Perry Education Ass'n v. Perry Local Educators' Ass'n, the Court examined petitioners' request to access a public school's internal mail system in order to distribute literature. ${ }^{169}$ In ruling on petitioners' First Amendment claim, the Court focused on the specific access sought by petitioner, which was access to the internal mail system, not access to the public school property in general. ${ }^{170}$ Similarly, in Pleasant Grove City, Utah v. Summum, while petitioners sought access to a public park -- which has long been viewed as a traditional or quintessential public forum -- the nature of the access sought by petitioners was access to install a permanent monument, instead of access for purposes of speaking or assembly. ${ }^{171}$

The Supreme Court has also made clear that, in order to constitute a designated public forum, the place in which speech occurs need not be an actual physical place. Rather, the Court has recently explained that public forums may also include virtual or "metaphysical" forums, like funding and solicitation schemes, ${ }^{172}$ the airwaves, ${ }^{173}$ cable television, ${ }^{174}$ and now, Internet

\footnotetext{
167473 U.S. 788, 790-93 (1985).

${ }^{168}$ See Cornelius, 473 U.S. at 801.

169420 U.S. 546, 39 (1975)

170460 U.S. 37, $46-47$ (1983).

171555 U.S. 460, 464 (2009).

172 See, e.g., Rosenberger v. Rectors and Visitors of the University of Virginia, 515 U.S. 819, 835 (1995)(university funding scheme for student publications constituted limited purpose designated public forum, in which viewpoint discrimination was prohibited); Cornelius v. NAACP Legal Defense and Education Fund, Inc., 473 U.S. 788, 797 (1985) (Combined Federal Campaign, an annual charitable fundraising drive conducted through the federal workplace during work hours through the voluntary efforts of public employees, was a nonpublic forum in which viewpoint discrimination was prohibited).
} 
forums for expression as well. ${ }^{175}$ For example, in Rosenberger v. Rectors and Visitors of the University of Virginia, Justice Kennedy made clear that the University of Virginia's funding scheme for student publications -- through which the university authorized the payment of outside contractors for the printing costs of a variety of student publications -- constituted a (limited purpose) designated public forum, within which viewpoint discrimination was prohibited. ${ }^{176}$

Justice Kennedy's interpretation of the public forum doctrine has been particularly sensitive to the importance of the evolution of the doctrine in light of modern developments and new forums for expression. His opinion in the case of International Society for Krishna Consciousness v. Lee ${ }^{177}$ is illustrative. In ISKCON v. Lee, members of the International Society for Krishna Consciousness (ISKCON) sought to engage in their religious practice of sankirtan, which involved "going into public places, disseminating religious literature, and soliciting funds to support the religion." ${ }^{178}$ The public places the practitioners chose in which to distribute literature and solicit funds were three major New York area airports -- Kennedy, La Guardia, and Newark -- all of which were owned and managed by the Port Authority of New York and New Jersey (a public entity). ${ }^{179}$ These airports and associated terminals serve as thoroughfares for

\footnotetext{
${ }^{173}$ See, e.g., Arkansas Educ. Television Comm’n v. Forbes, 523 U.S. 666, 680 (1998) (suggesting that if televised political debate had an "open-microphone format," it would constitute a designated public forum).

174 See, e.g., Denver Area Educational Telecomm. Consortium, Inc. v. F.C.C., 518 U.S. 727, 774-75 (1996) (Kennedy, J., concurring) (public access channels, which were channels that were available at low or no cost to members of the public, constituted designated public forums, and therefore cable operators' speech restrictions within such forums were subject to stringent scrutiny).

175 See Packingham v. North Carolina, 137 S. Ct. 1730, 1735 (2017) (identifying cyberspace as "the most important place[] ... for the exchange of views").

${ }^{176}$ See Rosenberger, 515 U.S. at830 (designating the student activity fund as a forum, despite being “a forum more in the metaphysical than in a spatial or geographic sense”).

177505 U.S. 672 (1992).

178 Lee, 505 U.S. at 674.

${ }^{179}$ See Lee, 505 U.S. at 675-76.
} 
approximately 100 million passengers annually, along with other members of the public. ${ }^{180}$ The Port Authority adopted a regulation prohibiting both the repetitive distribution of literature and the solicitation of funds within the airport terminals, and ISKCON sought a declaratory judgment that the regulation violated its members’ First Amendment rights. ${ }^{181}$

ISKCON advanced a functional interpretation of the public forum doctrine that emphasized the historic, speech-facilitating nature of transportation nodes (like rail and bus stations, wharves, and ports like Ellis Island), and contended that such sites historically served as important forums for expression. ${ }^{182}$ Chief Justice Rehnquist rejected this functional interpretation of the doctrine in favor of a narrower reading, and concluded that, "given the lateness with which the modern air terminal has made its appearance, it hardly qualifies for the description [from Hague v. CIO] of having immemorially ... time out of mind been held in trust and used for purposes of expressive activity." ${ }^{83}$ Accordingly, Rehnquist found that airport terminals did not constitute a traditional public forum. ${ }^{184}$ Furthermore, according to Rehnquist, airport terminals did not constitute "designated public forums" because the government owner was -- as is often the case in public forum litigation -- contesting their use for expressive purposes and could not be said to have "intentionally opened by their operators to such [expressive] activity.”"185 In nearly every public forum case before the courts, the government will be contesting the exercise of free speech rights on government property and will contend that it did not take the requisite steps to create a "designated public forum." 186

180 See Lee, 505 U.S. at 675.

181 See Lee, 505 U.S. at 676.

182 See Lee, 505 U.S. at 681.

${ }^{183}$ Lee, 505 U.S. at 680 (internal quotations omitted).

${ }^{184}$ See Lee, 505 U.S. at 680.

${ }^{185}$ Lee, 505 U.S. at 680

${ }^{186}$ Having concluded that the airport terminals were non-public forums, Rehnquist evaluated the Port Authority's ban on distribution of literature and solicitation of funds under a "reasonableness" standard, 
Justice Kennedy (writing for himself and Justices Blackmun, Stevens and Souter) criticized Rehnquist's miserly interpretation of the public forum doctrine, on the grounds that it left "almost no scope for the development of new public forums absent the rare approval of the government." ${ }^{187}$ Kennedy explained that the purposes of the public forum doctrine could not be given effect unless the Court undertakes an objective, functional inquiry, based on the actual characteristics and uses of the property. ${ }^{188}$ Under such an inquiry, Kennedy maintained, the Court should recognize that open public spaces and thoroughfares that are suitable for discourse, like airport terminals, should be conceptualized as public forums, whatever their historical pedigree. ${ }^{189}$ Absent such a functional interpretation, Kennedy argued, the public forum doctrine "retains no relevance in times of fast-changing technology." 190 Rejecting the strict “traditionality” inquiry adopted by Chief Justice Rehnquist, Justice Kennedy instead advanced a functional, evolving interpretation of the public forum doctrine, which took into account the fact that airport terminals are among the few open spaces where people have extended contact with other members of the public, and which, like streets, have areas that are "open to the public without restriction.”191

Justice Kennedy went on to criticize Rehnquist’s “designated public forum” analysis, under which the government is granted the discretion to "restrict speech by fiat." 192 Under Rehnquist's analysis, if the government does not expressly designate property as a public forum

under which the bans were readily upheld. See Lee, 505 U.S. at 685 ("The inconvenience to passengers and the burdens on Port Authority officials flowing from solicitation activity may seem small, but viewed against the fact that 'pedestrian congestion is one of the greatest problems facing the three terminals,' the Port Authority could reasonably worry that even such incremental effects would prove quite disruptive.”). ${ }^{187}$ Lee, 505 U.S. at 695 (Kennedy, J., concurring).

${ }^{188}$ See Lee, 505 U.S. at 695 (Kennedy, J., concurring).

${ }^{189}$ See Lee, 505 U.S. at 697 (Kennedy, J., concurring).

${ }^{190}$ Lee, 505 U.S. at 697 (Kennedy, J., concurring).

${ }^{191}$ Lee, 505 U.S. at 700 (Kennedy, J., concurring).

192 Lee, 505 U.S. at 694 (Kennedy, J., concurring). 
(and thereby assume the burden not to regulate speech on that property), the public enjoys no meaningful free speech rights on such property. ${ }^{193}$ This understanding of the "designated public forum" doctrine would allow the government to easily evade its affirmative obligations under the First Amendment. Rehnquist's failure to "recognize the possibility that new types of government property may be appropriate forums for speech [would] lead to a serious curtailment of our expressive activity,”194 as Justice Kennedy explained:

[U]nder the Court's view, the authority of the government to control speech on its property is paramount, for in almost all cases the critical step in the Court's analysis is a classification of the property that turns on the government's own definition or decision, unconstrained by an independent duty to respect the speech its citizens can voice there ....

The Court's approach is contrary to the underlying purposes of the public forum doctrine. The liberties protected by our doctrine ... are essential to a functioning democracy .... Public places are of necessity the locus for discussion of public issues, as well as protest against arbitrary government action. At the heart of our jurisprudence lies the principle that in a free nation citizens must have the right to gather and speak with other persons in public places. The recognition that certain government-owned property is a public forum provides open notice to citizens that their freedoms may be exercised there without fear of a censorial government, adding tangible reinforcement to the idea that we are a free people... [T] he policies underlying the [public forum] doctrine cannot be given effect unless we recognize that open, public spaces and thoroughfares that are suitable for discourse may be public forums, whatever their historical pedigree and without concern for a precise classification of the property. ${ }^{195}$

Justice Kennedy continued to develop his evolving, functional view of the public forum doctrine in the 1996 case of Denver Area Educational Telecommunications Consortium v.

\footnotetext{
193 See Lee, 505 U.S. at 697 (Kennedy, J., concurring) ("The requirements for such a designation are so stringent that I cannot be certain whether the category has any content left at all. In any event, it seems evident that under the Court's analysis today few, if any, types of property other than those already recognized as public forums will be accorded that status.”).

${ }^{194}$ Lee, 505 U.S. at 698 (Kennedy, J., concurring).

${ }^{195}$ Lee, 505 U.S. at 695-97 (Kennedy, J., concurring).
} 
F.C.C. ${ }^{196}$ In that case, the Court evaluated various F.C.C. orders implementing provisions of the Cable Television Consumer Protection and Competition Act that governed "indecent" and obscene programming. ${ }^{197}$ One of the challenged F.C.C. orders permitted cable operators to prohibit patently offensive or indecent programming on "public access channels" - channels that were available at low or no cost to members of the public. ${ }^{198}$ In Justice Kennedy's view, these public access channels met the definition of a "designated public forum" - "property that the State has opened for expressive activity by part or all of the public"199 - and therefore government-authorized speech restrictions by cable operators within such forums were subject to stringent scrutiny. ${ }^{200}$ First, Kennedy explained, the nominally private ownership of these forums (by cable operators) did not insulate them from the reach of the public forum doctrine: "[p]ublic access channels ... are public fora even though they operate over property to which the cable operator holds title.”201 Second, Kennedy explained, in providing public access channels under their franchise agreements:

[C]able operators therefore are not exercising their own First Amendment rights. [Rather,] [t]hey serve as conduits for the speech of others. ... Treating [public] access channels as public fora does not just place a label on them .... It defines the First Amendment rights of speakers seeking to use the channels. When property has been dedicated to public expressive activities, by tradition or government designation, access is protected by the First Amendment. ${ }^{202}$

196518 U.S. 727 (1996). In Denver Area, both the plurality (Justices Breyer, Stevens, O’Connor, and Souter) and the dissent (Justices Thomas and Scalia and Chief Justice Rehnquist) refused to characterize the forum at issue as a public forum.

${ }^{197}$ See Denver Area Educ. Telcoms. Consortium, 518 U.S. at 735.

198 See Denver Area Educ. Telcoms. Consortium, 518 U.S. at 736.

199 Denver Area Educ. Telcoms. Consortium, 518 U.S. at 791 (Kennedy J., joined by Ginsburg, J., concurring in part, concurring in the judgment in part, and dissenting in part) (quoting International Soc. for Krishna Consciousness, Inc. v. Lee, 505 U.S. 672, 678 (1992)).

${ }^{200}$ See Denver Area Educ. Telcoms. Consortium, 518 U.S. at 794 (quoting Lee, 505 U.S. at 678) ("Regulations of speech content in a designated public forum, whether of limited or unlimited character, are 'subject to the highest scrutiny' and 'survive only if they are narrowly drawn to achieve a compelling state interest."”).

${ }^{201}$ Denver Area Educ. Telcoms. Consortium, 518 U.S. at 792.

${ }^{202}$ Denver Area Educ. Telcoms. Consortium, 518 U.S. at 793-94. 
Justice Kennedy explained that the purpose underlying the public forum doctrine - to ensure open, nondiscriminatory access to the means of communication - was evident in the legislation under which the F.C.C. was regulating, and that the public forum doctrine must be meaningfully extended to new media:

Giving Government free rein to exclude speech it dislikes ... would have pernicious effects in the modern age. Minds are not changed in streets and parks as they once were. To an increasing degree, the more significant interchanges of ideas and shaping of public consciousness occur in mass and electronic media. The extent of public entitlement to participate in those means of communication may be changed as technologies change; and in expanding those entitlements the Government has no greater right to discriminate on suspect grounds than it does when it effects a ban on speech against the backdrop of the entitlements to which we have been more accustomed. ${ }^{203}$

Kennedy concluded that in order for the First Amendment to remain meaningful in the modern era, the public forum doctrine must be extended to new technologies, to prevent government (and government-like actors operating public forums) from exercising the power to discriminate against disfavored expression. ${ }^{204}$

Justice Kennedy continued to develop his expansive, functional view of the public forum doctrine in the 2017 case of Packingham v. North Carolina. ${ }^{205}$ In that case, Lester Packingham -an individual who was required to register as a sex offender after having sex with a 13 year old girl when he was 21 -- challenged a North Carolina law that prohibited any and all use by

\footnotetext{
${ }^{203}$ Denver Area Educ. Telcoms. Consortium, 518 U.S. at 802-03 (citations omitted).

${ }^{204}$ See Denver Area Educ. Telcoms. Consortium, 518 U.S. at 776-77 (“[A]s broadcast, cable, and the cybertechnology of the Internet and the World Wide Web approach the day of using a common receiver, we can hardly assume that standards for judging the regulation of one of them will not have immense, but now unknown and unknowable, effects on the others.”).

205137 S. Ct. 1730 (2017).
} 
registered sex offenders of social media sites like Twitter and Facebook. ${ }^{206}$ Packingham, in violation of the state law, created a Facebook account using a pseudonym and posted a message praising God and Jesus for his good fortune after a state court dismissed a traffic ticket against him. ${ }^{207}$ After police tracked him down and identified him as the creator of the pseudonymous Facebook account, Packingham was convicted of felony charges for violating the state law and given a suspended prison sentence. ${ }^{208}$ Packingham challenged the law, claiming it violated his First Amendment rights. ${ }^{209}$

\begin{abstract}
${ }^{206}$ See Packingham, 137 S. Ct at 1734; N.C. Gen. Stat. Ann. Sections 14-202.5(a) (2015) makes it a felony for a registered sex offender to "access a commercial social networking Web site where the sex offender knows that the site permits minor children to become members or to create or maintain person Web pages." The statute defines "commercial social networking Web site" as a website that (1) "[i]s operated by a person who derives revenue from membership fees, advertising, or other sources related to the operation of the Web site"; (2) "[f]acilitates the social introduction between two or more persons for the purposes of friendship, meeting other persons, or information exchanges” (3) "[a]llows users to create Web pages or personal profiles that contain information such as the name or nickname of the user, photographs placed on the personal Web page by the user, other personal information about the user, and links to other personal Web pages on the commercial social networking Web site of friends or associates of the user that may be accessed by other users or visitors to the Web site" and (4) "[p]rovides users or visitors ... mechanisms to communicate with other users, such as a message board, chat room, electronic mail, or instant messenger.” N.C. Gen. Stat. Ann. Sections 14-202.5 (b). Two exceptions to this definition are provided. The statutory bar does not extend to websites that "[p]rovid[e] only one of the following discrete services: photo-sharing, electronic mail, instant messenger, or chat room or message board platform" nor to websites that have as their "primary purpose the facilitation of commercial transactions involving goods or services between [their] members or visitors.” §14-202.5(c)(1),(2).
\end{abstract}

${ }^{207}$ Packingham, who had created a Facebook account under the pseudonym "J.R. Gerrard," was relieved to learn that a state court had dismissed a traffic ticket against him and in response logged onto his Facebook page and posted the following statement:

Man God is Good! How about I got so much favor they dismissed the ticket before court even started? No fine, no court cost, no nothing spent. . . . . . Praise be to GOD, WOW! Thanks JESUS! Packingham, 137 S. Ct at 1734.

A police officer investigating registered sex offenders who were thought to be violating the state law prohibiting them from accessing social media discovered that a traffic citation for Packingham had been dismissed around the time of this Facebook post. See id. The officer obtained a search warrant and determined that Packingham was the author of the above post on Facebook, which led to Packingham's conviction for violating the state statute. See id.

${ }^{208}$ See Packingham, 137 S. Ct at 1734.

${ }^{209}$ See Packingham, 137 S. Ct at 1734. 
Justice Kennedy, in the Opinion of the Court, struck down the state law's broad prohibition on access to social media sites by registered sex offenders, explaining that social media sites like Facebook and Twitter serve important free speech functions and that prohibiting registered sex offenders (of whom there were 20,000 in the state, whose status as sex offenders could endure for 30 years or more) impermissibly thwarted those important free speech functions. ${ }^{210}$ Kennedy focused in particular on the important functions served by the public forum doctrine, explaining that: “A fundamental principle of the First Amendment is that all persons have access to places where they can speak and listen, and then, after reflection, speak and listen once more.”211 Kennedy noted that streets and parks were the "quintessential forum[s] for the exercise of First Amendment rights" and that such traditional public forums -- even in the modern age -- are still essential venues for citizens to exercise these rights -- for "public gatherings to celebrate some views, to protest others, or simply to learn and inquire." ${ }^{212}$ He acknowledged that the Court had some difficulty in the past determining which venues beyond streets, sidewalks, and parks should be considered public forums, but that the emergence of the Internet in general and social media on the Internet in particular simplified such inquiries: "While in the past there may have been difficulty in identifying the most important places... for the exchange of views, today the answer is clear... It is cyberspace - the 'vast democratic forums of the Internet' in general, and social media in particular." ${ }^{213}$ Kennedy went on to identify Facebook and Twitter as the most significant social media forums, and characterized Twitter in particular as a forum where "users can petition their elected representatives and otherwise engage with them in a direct manner," since "Governors of all 50 States and almost every Member of

${ }^{210}$ See Packingham, 137 S. Ct at 1734, 1743.

${ }^{211}$ Packingham, 137 S. Ct at 1735.

${ }^{212}$ Packingham, 137 S. Ct at 1735.

${ }^{213}$ Packingham, 137 S. Ct at 1735. 
Congress" employ Twitter as a forum in which to engage with constituents. ${ }^{214}$ Kennedy noted that, as with traditional public forums of streets, sidewalks, and parks, social media sites offer "relatively unlimited, low-cost capacity for communication of all kinds," where users can "engage in a wide array of protected First Amendment activity on topics 'as diverse as human thought.'"215 Social media, Kennedy explained, "allows users to gain access to information and communicate with one another about it on any subject that might come to mind... [and constitute] principal sources for knowing current events, ... speaking and listening in the modern public square, ... exploring the vast realms of human thought and knowledge, ... [and are] the most powerful mechanisms available to a private citizen to make his or her voice heard." ${ }^{216}$ In summary, Kennedy observed that the Internet in general and social media in particular have "vast potential to alter how we think, express ourselves, and define who we want to be."217 In light of the important role social media serve in advancing free speech values, the Court held that the state law's sweeping ban on registered sex offenders' access to social media -- forums that are "integral to the fabric of modern society and culture" -- could not withstand constitutional scrutiny. ${ }^{218}$

\section{B. Public Forums on Privately-Owned Property}

Although public forums generally involve government-owned property, the Court has made clear that, in order to constitute a public forum, the space at issue need not be owned by the government; rather, a public forum can exist where the underlying property is privately-owned

\footnotetext{
${ }^{214}$ Packingham, 137 S. Ct at 1735.

${ }^{215}$ Packingham, 137 S. Ct at 1735 (quoting Reno v. American Civil Liberties Union, 521 U.S. 844, 868 (1997)).

${ }^{216}$ Packingham, 137 S. Ct at 1737.

${ }^{217}$ Packingham, $137 \mathrm{~S}$. Ct at 1736.

${ }^{218}$ Packingham, 137 S. Ct at 1738.
} 
but controlled by the government. ${ }^{219}$ If the government seeks to regulate private property that it has opened up and designated for use as a public forum, then such regulation must be consistent with the strictures of the First Amendment and with the strictures of the public forum doctrine in particular. For example, in Southeastern Promotions v. Conrad, the Court held that a privatelyowned theatre under long-term lease to the city of Chattanooga that was "designed for and dedicated to expressive activities”220 would be considered a designated public forum and therefore the City could not censor the production of the musical "Hair" based on disapproval of its content. ${ }^{221}$ Similarly, in Denver Area, Justice Kennedy explained in his concurring opinion that privately-owned cable stations that were controlled by the government and opened up by the government for use by the public constituted designated public forums in which government regulation was subject to strict scrutiny. ${ }^{222}$ As discussed above, Denver Area involved various Federal Communications Commission orders implementing provisions of the 1984 Cable Television Consumer Protection and Competition Act that governed "indecent" and obscene programming, one of which permitted cable operators to prohibit patently offensive or indecent

\footnotetext{
${ }^{219}$ Indeed, the Supreme Court indicated in the seminal public forum case of Hague v. CIO that the public or private ownership of the property under consideration was not dispositive of the issue of whether the property was a public forum. See Hague v. Committee for Indus. Org., 307 U.S. 496, 515 (1939). In that case the Court, explained that " $[w]$ herever the title of streets and parks may rest, they have immemorially been held in trust for the use of the public, and time out of mind, have been used for purposes of assembly, communicating thoughts between citizens, and discussing public questions.... [and accordingly, the] privilege of a citizen of the United States to use the streets and parks for communication of views on national questions ... must not, in the guise of regulation, be abridged or denied.” Id. (emphasis added).

220420 U.S. 546, 555 (1975). See also Cornelius v. NAACP Legal Def. \& Edu. Fund, 473 U.S. 788, 8011985) (In order to invoke the public forum doctrine, "a speaker must seek access to public property or to private property dedicated to public use to evoke First Amendment concerns.") (emphasis added).

${ }^{221}$ See Southeastern Promotions, Ltd, 420 U.S. at 555 (unconstitutional for municipal board of City of Chattanooga to reject petition to stage the musical "Hair" at a city-leased theater on the grounds that the production would not be "in the best interest of the community," because theater was a designated public forum, notwithstanding the fact that the theater was privately owned, and because rejection constituted prior restraint on protected speech without adequate substantive and procedural safeguards.)

${ }^{222}$ See Denver Area Educ. Telcoms. Consortium v. FCC, 518 U.S. 727, 774 (1996) (Kennedy, J., concurring).
} 
programming on public access channels. ${ }^{223}$ Those defending the constitutionality of the Act's provisions argued that the public forum doctrine was not implicated by the Act's prohibitions, because the conduits for speech at issue were privately owned and because this order merely enabled private cable operators to implement speech restrictions, and therefore that the First Amendment was not implicated. ${ }^{224}$ Kennedy rejected both arguments. First, Kennedy explained that the Act imposed impermissible content-based restrictions within a designated public forum - notwithstanding the fact that the restrictions would be imposed by private cable operators. Kennedy explained:

The public access channels ... are available at low or no cost to members of the public, often on a first-come, first-served basis. .. Public access channels meet the definition of a public forum. We have recognized two kinds of public fora. The first and most familiar are traditional public fora, like streets, sidewalks, and parks, which by custom have long been open for public assembly and discourse.... The second category of public property is the designated public forum, whether of a limited or unlimited character -- property that the State has opened for expressive activity by part or all of the public. . .

Public access channels fall in the second category. Required by the franchise authority as a condition of the franchise and open to all comers, [public access channels] are a designated public forum of unlimited character. The House Report for the 1984 Cable Act ... characterized public access channels as "the video equivalent of the speaker's soap box or the electronic parallel to the printed leaflet. They provide groups and individuals who generally have not had access to the electronic media with the opportunity to become sources of information in the electronic marketplace of ideas." . . . Public fora do not have to be physical gathering places, ... nor are they limited to property owned by the government... Indeed, in the majority of jurisdictions, title to some of the most traditional of public fora, streets and sidewalks, remains in private hands....Public access channels are analogous; they are public fora even though they operate over property to which the cable operator holds title.....225

Kennedy went on to reject the argument that the Act would merely require private property owners (the cable operators) to implement the speech restrictions of their choosing and were merely exercising their own First Amendment rights: "In providing public access channels under

\footnotetext{
${ }^{223}$ See Denver Area Educ. Telcoms. Consortium, 518 U.S. at 736.

${ }^{224}$ See Denver Area Educ. Telcoms. Consortium, 518 U.S. at 737.

${ }^{225}$ Denver Area Educ. Telcoms. Consortium, 518 U.S. at 791-92 (emphasis added).
} 
their franchise agreements, cable operators ... are not exercising their own First Amendment rights. [Rather, cable operators] serve as conduits for the speech of others. ... By enacting a law in 1992 excluding indecent programming from protection ..., the Federal Government at the same time ratified the public forum character of public access channels but discriminated against certain speech based on its content." 226 Accordingly, Kennedy made clear that government restrictions imposed on privately-owned property can constitute impermissible speech restrictions within a designated public forum, regardless of the fact that the forum was privately owned.

In summary, from its initial inception in the mid-twentieth century to its complex development and evolution over the next century, the public forum doctrine has expanded to encompass not just physical property owned by the government, but also "metaphysical" forums -- including Internet forums -- that are owned or controlled by government officials. As a result of this evolution, the public forum doctrine continues to be a vibrant and essential doctrine for the protection of speech against censorship by government officials in new mediums opened up by government officials for expressive purposes.

C. The Government Speech Doctrine: Distinguishing "Government Speech" from Public Forums for Private Speech

In several recent cases, the Supreme Court has distinguished situations in which the government has established public forums for speech -- in which individuals enjoy the robust protections of the public forum doctrine -- from situations in which only the government itself is speaking -- in which the protections of the Free Speech Clause of the First Amendment do not

${ }^{226}$ Denver Area Educ. Telcoms. Consortium, 518 U.S. at 793. 
apply. In a line of cases beginning with Rust v. Sullivan ${ }^{227}$ in 1991, the Court has made clear that when the government itself, or government officials, are speaking, the mandates of the public forum doctrine -- including the prohibition against viewpoint discrimination by the government - do not apply. The Court has since expanded the category of government speech -- in which viewpoint discrimination by the government is permitted -- to include cases in which the government itself is the speaker as well as instances in which the government is using private speakers to transmit its own message. ${ }^{228}$

The distinction between cases in which the government is speaking and cases in which it is creating a public forum for the speech of others is not always a clear one, as is seen in cases like Pleasant Grove City, Utah v. Summum, which involved government restrictions on a private organization's requested access to a public park. ${ }^{229}$ In that case, a religious organization called Summum sought to erect a stone monument in Pioneer Park, a public park in Pleasant Grove City, Utah. The monument that the Summum organization sought to erect in the park contained

227500 U.S. 173 (1991). Rust v. Sullivan involved a challenge to a set of 1988 regulations issued under Title X of the Public Health Service Act of 1970, which prohibited Title X project grantees from, inter alia, providing counseling concerning the use of abortion or providing referral for abortion as a method of family planning, even upon request from patients. See id. at 179. These regulations were challenged by Title X grantees, who claimed that the regulation's “gag rule” violated their First Amendment rights and amounted to illegal viewpoint discrimination within a designated public forum. See id. at 181. The Court, in a 5-4 opinion, upheld the regulations and held that the government could constitutionally decide to "selectively fund a program to encourage certain activities it believes to be in the public interest, without at the same time funding an alternate program which seeks to deal with the problem in another way." Id. at 193. Although the Court did not at the time characterize Rust as a case involving government speech, in subsequent cases the Court explained that "the counseling activities of the doctors under Title X amounted to government speech" and held that "viewpoint-based funding decisions can be sustained in instances in which the government is itself the speaker or instances, like Rust, in which the government used private speakers to transmit information pertaining to its own program.” See Legal Services Corp. v. Velazquez, 531 U.S. 533, 541 (2001).

${ }^{228}$ See Legal Services Corp., 531 U.S. at 541 (explaining that "viewpoint-based funding decisions can be sustained in instances in which the government is itself the speaker or ... in which the government used private speakers to transmit information pertaining to its own program" and stating that "when the government disburses public funds to private entities to convey a governmental message, it may take legitimate and appropriate steps to ensure that its message is neither garbled nor distorted by the grantee.")

${ }^{229} 555$ U.S. 460, 464 (2009). 
the Seven Aphorisms of Summum, which the organization believes were inscribed on the tablet that God handed down to Moses on Mount Sinai. At the time of Summum's request to install the monument, Pioneer Park contained fifteen monuments, eleven of which had been donated by private organizations, including a Ten Commandments monument that had been donated by the Fraternal Order of Eagles. The City of Pleasant Grove refused to allow Summum to erect its desired monument in the park, and Summum sued, claiming that the City's actions -- by accepting other donated monuments while refusing Summum's proffered donation -- constituted illegal viewpoint discrimination within a public forum. ${ }^{230}$

The lower court analyzed Summum's request for access to the public park under the public forum doctrine and found for Summum. ${ }^{231}$ The Supreme Court, however, unanimously ruled in favor of the City and held that forum analysis was inappropriate. ${ }^{232}$ The Court held that, in deciding which permanent monuments were to be displayed on public property, the government was engaging in government speech, and was not impermissibly discriminating on the basis of viewpoint within a public forum for private speech. ${ }^{233}$ While acknowledging that public parks are traditional public forums to which individuals have a right of access for purposes such as delivering speeches and holding marches and demonstrations, the Court explained that forum analysis did not apply to the specific type of access sought here -- the erection of a permanent monument in the public park. ${ }^{234}$ The Court indicated that the relevant inquiry involved whether the forum could accommodate the types of requests for access from private parties at issue, and concluded that it could not:

\footnotetext{
${ }^{230}$ See Summum, 555 U.S. at 466.

${ }^{231}$ See Summum, 555 U.S. at 464.

232 See Summum, 555 U.S. at 481

${ }^{233}$ See Summum, 555 U.S. at 472.

${ }^{234}$ See Summum, 555 U.S. at 466.
} 
The forum doctrine has been applied in situations in which governmentowned property or a government program was capable of accommodating a large number of public speakers without defeating the essential function of the land or the program. For example, a park can accommodate many speakers and, over time, many parades and demonstrations....By contrast, public parks can accommodate only a limited number of permanent monuments ... It is hard to imagine how a public park could be opened for the installation of permanent monuments by every person or group wishing to engage in that form of expression. . . [Indeed,] if public parks were considered to be traditional public forums for the purpose of erecting privately donated monuments, most parks would have little choice but to refuse all such donations ... and application of forum analysis would lead almost inexorably to the closing of the forum. ${ }^{235}$

Holding that the selection of which permanent monuments to allow in a public park constituted government speech, the Court concluded that the City's selection decision was not subject to scrutiny under the Free Speech Clause. ${ }^{236}$

The Court adopted a similar approach in analyzing a state program for specialty license plates in the recent case of Walker v. Texas Div., Sons of Confederate Veterans. ${ }^{237}$ In Walker, the Sons of Confederate Veterans -- a non-profit organization that works to preserve the memory and reputation of soldiers who fought for the confederacy in the Civil War -- applied to have a new specialty license plate recognized and issued by the Texas Department of Motor Vehicles (TDMV). ${ }^{238}$ The Sons of Confederate Veterans sought approval for its specialty license plate design that featured the Confederate battle flag. ${ }^{239}$ The Texas Department of Motor Vehicles had a policy stating that it "may refuse to create a new specialty license plate if the design might be

\footnotetext{
${ }^{235}$ Summum, 555 U.S. at 478-80.

${ }^{236}$ See Summum, 555 U.S. at 481. The Court explained, "the City’s decision to accept certain privately donated monuments while rejecting [Summum's] is best viewed as a form of government speech. As a result, the City's decision is not subject to the Free Speech Clause ....” Id. at 481. The Court held, however, that the City's decisions must comply with the Establishment Clause of the First Amendment. ${ }^{237} 135$ S. Ct. 2239 (2015).

${ }^{238}$ See Walker, 135 S. Ct. at 2245.

${ }^{239}$ See Walker, 135 S. Ct. at 2245.
} 
offensive to any member of the public." 240 Although hundreds of other specialty license plates had been approved by Department -- including a "Buffalo Soldiers" license plate that certain Native Americans objected to, on the grounds that it was offensive to them -- the Department refused to approve the Sons of Confederate Veterans proposed plate on the ground that it was potentially offensive to others. ${ }^{241}$ The Sons of the Confederate Veterans organization sued the state, claiming that the state had opened up a public forum for speech when it created the specialty license plate program and when the Department thereafter approved hundreds of other plates with a variety of messages (some of which were offensive to some groups). ${ }^{242}$

The Supreme Court disagreed. ${ }^{243}$ Relying heavily on its Pleasant Grove v. Summum decision, the Court in a 5-4 decision concluded that the state's specialty license plate program constituted government speech and therefore that government decisions in selecting which plates to approve and which to reject did not create a public forum for speech (and need not be viewpoint neutral). ${ }^{244}$ In adopting the government speech framework, the Court primarily looked to three factors. First, the Court explained that license plates, like permanent monuments in public parks, "long have communicated messages from the States." 245 Second, the Court explained that license plates, like permanent monuments in public parks, are "often closely identified in the public mind with the [State]" since they serve as a form of a government ID, notwithstanding the fact that private parties were involved in the creation of the specialty license plate messages. ${ }^{246}$ Third, the Court observed that the state maintained direct control over the

\footnotetext{
${ }^{240}$ Walker, 135 S. Ct. at 2244-45.

${ }^{241}$ See Walker, 135 S. Ct. at 2258, 2245.

${ }^{242}$ See Walker, 135 S. Ct. at 2245.

243 See Walker, 135 S. Ct. at 2250.

244 See Walker, 135 S. Ct. at 2246.

${ }^{245}$ Walker, 135 S. Ct. at2248

${ }^{246}$ Walker, 135 S. Ct. at 2248.
} 
messages conveyed on its specialty license plates. ${ }^{247}$ In the majority's view, all three factors pointed to the conclusion that the messages on the specialty license plates constituted government speech, not private speech within a designated public forum opened up by the government, and therefore that the strictures of the Free Speech Clause did not apply. ${ }^{248}$ The four dissenting Justices criticized the majority's decision and warned that the government speech doctrine, if applied too broadly, could swallow up the First Amendment's crucial protections for unpopular speech. ${ }^{249}$

In subsequent cases, the Court has made clear that the Walker decision constituted the outer limits of the government speech doctrine and re-emphasized the dangers to free speech in applying the government speech doctrine too broadly. In the recent case of Matal v. Tam, which involved the United States Trademark Office's refusal to register the mark "The Slants" for an Asian-American rock band on the principal register on the grounds that the mark was likely to be disparaging toward persons of Asian descent, in violation of the Disparagement Clause of the

\footnotetext{
${ }^{247}$ See Walker, 135 S. Ct. at 2249.

${ }^{248}$ See Walker, 135 S. Ct. at 2249. The Court emphasized that the Establishment Clause was still relevant in analyzing whether government speech ran afoul of the First Amendment, for example, in cases where the government adopted a religious message on a specialty license plate.

${ }^{249}$ See Walker, 135 S. Ct. at 2254 (Alito, J., dissenting). Justice Alito criticized the majority’s characterization of the state specialty license plate program as government speech instead of a limited public forum and claimed that the majority's approach severely limited the First Amendment's protections for unpopular viewpoints:
}

The Court's decision passes off private speech as government speech and, in doing so, establishes a precedent that threatens private speech that government finds displeasing. Under our First Amendment cases, the distinction between government speech and private speech is critical. The First Amendment does not regulate government speech, and therefore when government speaks, it is free to select the views that it wants to express.... By contrast, in the realm of private speech or expression, government regulation may not favor one speaker over another.... Unfortunately, the Court's decision categorizes private speech as government speech and thus strips it of all First Amendment protection.... This capacious understanding of government speech takes a large and painful bite out of the First Amendment. Id. at 2254-55 (Alito, J., dissenting) (citations omitted, internal quotation marks omitted). 
Lanham Act, ${ }^{250}$ the Trademark Office argued that its selection of which marks to register and which to refuse constituted government speech, not private speech, and therefore its selection decisions were not subject to scrutiny under the Free Speech Clause. ${ }^{251}$ The Supreme Court unanimously rejected the government's attempt to extend the government speech doctrine to this context, and held that the Trademark Office's refusal to register the mark at issue amounted to illegal viewpoint discrimination against private speech, not government speech that was immune from scrutiny under the Free Speech Clause. ${ }^{252}$ In so doing, the Court cautioned against the government's proposed "huge and dangerous" expansion of the government speech doctrine: ${ }^{253}$

[W] hile the government-speech doctrine is important—indeed, essential—it is a doctrine that is susceptible to dangerous misuse. If private speech could be passed off as government speech by simply affixing a government seal of approval, government could silence or muffle the expression of disfavored viewpoints. For this reason, we must exercise great caution before extending our governmentspeech precedents. ${ }^{254}$

III. Forum Analysis of Government Officials' Blocking Constituents from Accessing Their $\underline{\text { Social Media Sites }}$

\section{A. Introduction}

Having explored the contours of the modern public forum doctrine and the government speech doctrine, in this Part, I turn to an analysis of the actions of government officials in blocking their constituents from accessing their social media accounts. In both the case

\footnotetext{
${ }^{250}$ See Matal v. Tam, 137 S. Ct. 1744, 1751 (2017). The Disparagement Clause of the Lanham Act of 1946 prohibits the registration on the Principal Register of trademarks that "consists of or comprises immoral, deceptive, or scandalous matter; or matter which may disparage or falsely suggest a connection with persons, living or dead, institutions, beliefs, or national symbols, or bring them into contempt, or disrepute.” 15 U.S.C. § 1052(a).

${ }^{251}$ See Matal, 137 S. Ct. at 1757.

252 See Matal, 137 S. Ct. at 1760.

${ }^{253}$ Matal, 137 S. Ct. at 1760 ("For if the registration of trademarks constituted government speech, other systems of government registration could easily be characterized in the same way."). See also Steven G. Gey, Why Should the First Amendment Protect Government Speech When the Government Has Nothing to Say?, 95 Iowa L. Rev. 1259, 1311 (2010) (claiming that courts must "restrict the application of the government speech doctrine to situations where the exercise of free speech rights by private citizens would thwart the government's ability to communicate with the public").

${ }^{254}$ Matal, 137 S. Ct. at 1758.
} 
involving Loudoun County Commissioner Randall and the case involving Maryland Governor Hogan, constituents were blocked from commenting on the government officials' Facebook page. ${ }^{255}$ In Hogan's case, his constituents were blocked pursuant to an official government social media policy, which provided that his Facebook page was established to serve as a "forum for constructive and respectful discussion with and among users" and that constituents' comments on Hogan's Facebook page could be deleted "at any time . . . without providing justification."256 Pursuant to this policy, as discussed above, Hogan and his administration blocked constituents from commenting on his Facebook page after they questioned or criticized his policies. ${ }^{257}$ In the Virginia case, Loudoun County Commissioner Phyllis Randall operated an unofficial Facebook page and made a unilateral decision to block her constituent's comment (not pursuant to a government social media policy). ${ }^{258}$ In both cases, constituents were blocked and their comments were removed because of the government official's disagreement with the viewpoint expressed by the constituent. The Maryland case, in which the American Civil Liberties Union challenged the blocking of constituents pursuant to the Governor's social media policy, was settled, with the Hogan administration agreeing to modify its social media policy to comply with the dictates of the First Amendment. ${ }^{259}$ The Virginia case is ongoing, as I discuss below.

B. County Commissioner Randall's Unofficial Facebook Page as Public Forum: Davison v. Loudoun County Board of Supervisors

\footnotetext{
${ }^{255}$ See discussion supra.

${ }^{256}$ Exhibit A to Complaint, Laurenson et al. v. Hogan, No. 8:17 Civ. 02162-DKC (filed on Aug. 1, 2017)

${ }^{257}$ See Complaint at 3, Laurenson et al. v. Hogan, No. 8:17 Civ. 02162-DKC (filed on Aug. 1, 2017)

${ }^{258}$ See Davison v. Loudoun Cnty. Bd. of Supervisors, 267 F. Supp. 3d 702, 715 (E.D. Va. May 10, 2017)

${ }^{259}$ See Laurenson v. Hogan, ACLU MARYLAND, https://www.aclu-md.org/en/cases/laurenson-v-hogan (last visited July 28, 2018) ("The ACLU reached a settlement in the case that includes a new social media policy that will govern Gov. Hogan's Facebook page, mandates the creation of a second Facebook page dedicated to providing a public forum where constituents can raise a host of issues for the governor's attention, and creates an appeals process for constituents who feel their comments have been improperly deleted, or that they have been wrongfully blocked.”). See generally Office of the Governor Social-Media Policy, Office of Governor Larry Hogan,http://governor.maryland.gov/wpcontent/uploads/2018/03/social-media-policy.pdf (last visited July 28, 2018).
} 
In Davison v. Loudoun County Board of Supervisors, the parties primarily dispute whether the unofficial Facebook page of Chair Phyllis Randall -- from which constituent Brian Davison was blocked after he posted a critical comment -- constituted a public forum for purposes of the First Amendment. ${ }^{260}$ Randall argues that, in creating her unofficial Facebook page, she did not create a public forum for the private speech of others. ${ }^{261}$ She maintains instead that the Facebook page is her own private speech forum -- on which she cannot be compelled to adopt someone else's comments -- or, in the alternative, that her Facebook page is government speech, which is immune from scrutiny under the Free Speech Clause. ${ }^{262}$ Randall argues further that the public forum doctrine is inapplicable because Facebook is a private entity. ${ }^{263}$ She maintains that the public forum doctrine is only applicable to publicly-owned property and cannot properly be invoked in the context of a privately-owned website like Facebook. ${ }^{264}$ Adverting to the fact that Facebook has its own content removal guidelines and its own First Amendment rights at stake, Randall maintains that her decision to block access to her page on this privately-owned forum does not implicate the public forum doctrine. ${ }^{265}$ In response, her blocked constituent Davison argues that, despite the fact that Randall's Facebook page is unofficial, it nonetheless constitutes a government-run and government-controlled forum, on

\footnotetext{
${ }^{260}$ See Davison v. Loudoun Cnty. Bd. of Supervisors, 267 F. Supp. 3d 702, 711 (E.D. Va. May 10, 2017).

${ }^{261}$ See Defendant-Appellant Phyllis J. Randall's Informal Opening Brief at 7, Davison v. Loudoun Cnty. Bd. of Supervisors, 267 F. Supp. 3d 702 (E.D. Va. May 10, 2017).

${ }^{262}$ See id. at 7-10.

263 See id. at 8.

${ }^{264}$ See id. at 7.

${ }^{265}$ See id. at 8. See also Defendants Loudoun County Board of Supervisors and Phyllis Randall's Memorandum In Support of Motion For Summary Judgment Filed Pursuant to Fed. R. Civ. P. 56(a) at 17, Davison v. Loudoun Cnty. Bd. of Supervisors, 267 F. Supp. 3d 702, (E.D. Va. 2017) (No. 1:16 Civ. 00932) ("Facebook ... retains control of Facebook page content by imposing specific terms and conditions ... As conceded by Davison, due to Facebook's internal software, anyone can mark his postings as span which would cause Facebook to suppress his comments, without any action taken by the government ... It is Facebook's created software which allows this to occur and to which Davison objects ....”).
} 
which Randall expressly invited constituents to comment on any and all manner of subjects, and that Commissioner Randall thereby created a designated public forum, within which viewpoint discrimination is impermissible. ${ }^{266}$

The district court in Davison v. Loudoun County Board of Supervisors properly rejected Randall's argument that her Facebook page was her personal/private speech, as well as her argument in the alternative that the page constituted government speech immune from public forum analysis. First, in analyzing whether Randall's Facebook page was personal or governmental, the district court looked to whether her actions in connection with the page had a sufficiently close nexus with the state such as to be fairly treated as the actions of the government itself, considering the totality of the relevant circumstances. ${ }^{267}$ The district court observed, on the one hand, that certain facts weighed in favor of considering the Facebook page as Randall's private speech. ${ }^{268}$ Randall's official duties as County Commissioner do not include the maintenance of a social media site, and Randall's Facebook page will not revert to the county government when Randall leaves office. ${ }^{269}$ Further, Randall does not use government-issued electronic devices to maintain her Facebook page, and much of her Facebook activity generally takes place outside of her physical government office and outside of her official working hours. ${ }^{270}$ However, the district court was more persuaded by the factors weighing in favor of considering Randall's Facebook page to be governmental and having a sufficiently close nexus

\footnotetext{
${ }^{266}$ See Second Amended Complaint at 8, Davison v. Loudoun Cnty. Bd. of Supervisors, 267 F. Supp. 3d 702 (E.D. Va. May 10, 2017).

${ }^{267}$ See Davison v. Loudoun Cnty. Bd. of Supervisors, 267 F. Supp. 3d 702, 720 (E.D. Va. May 10, 2017) ("[T]his case concerns apparently private actions that have a sufficiently close nexus with the State to be fairly treated as the actions of the State itself.”) (internal quotations omitted).

268 See Davison v. Loudoun Cnty. Bd. of Supervisors, 267 F. Supp. 3d 702, 712 (E.D. Va. May 10, 2017).

${ }^{269}$ See Davison v. Loudoun Cnty. Bd. of Supervisors, 267 F. Supp. 3d 702, 712 (E.D. Va. May 10, 2017).

270 See Davison v. Loudoun Cnty. Bd. of Supervisors, 267 F. Supp. 3d 702, 712 (E.D. Va. May 10, 2017).
} 
with the state. ${ }^{271}$ First, and most importantly, Randall used her Facebook page as a tool of governance and as a vehicle to engage with her constituents with respect to her official government activities. ${ }^{272}$ She expressly requested that her citizens use her Facebook page as a channel for "back and forth constituent conversations" with her, and the content on her page is predominantly related to her official government actions and duties. ${ }^{273}$ In addition, her Facebook page has been designated in many ways as governmental not personal. ${ }^{274}$ The title of the page includes Randall's governmental title, the page is designated as that of a government official, and lists Randall's official email address, telephone number, and web address. ${ }^{275}$ Furthermore, Randall's motivation for banning Davison from her Facebook page was because he criticized her colleagues in county government. ${ }^{276}$ The district court found that this censorial motive related to the conduct of Randall's official government duties. ${ }^{277}$ In considering the totality of the circumstances, the court concluded that Randall's operation of her Facebook page was governmental -- not private -- action. ${ }^{278}$

Next, the district court properly rejected Randall's argument that her Facebook page constituted government speech that was immune from scrutiny under the Free Speech Clause. ${ }^{279}$ Finally, the district court concluded, based on the multifactor designated public forum analysis, that the page constituted a designated public forum for expression. ${ }^{280}$ The court observed that the

\footnotetext{
${ }^{271}$ See Davison v. Loudoun Cnty. Bd. of Supervisors, 267 F. Supp. 3d 702, 713 (E.D. Va. May 10, 2017) (describing Randall's actions as arising “out of public, not personal, circumstances”).

${ }^{272}$ See Davison v. Loudoun Cnty. Bd. of Supervisors, 267 F. Supp. 3d 702, 713 (E.D. Va. May 10, 2017).

${ }^{273}$ See Davison v. Loudoun Cnty. Bd. of Supervisors, 267 F. Supp. 3d 702, 713 (E.D. Va. May 10, 2017).

${ }^{274}$ See Davison v. Loudoun Cnty. Bd. of Supervisors, 267 F. Supp. 3d 702, 714 (E.D. Va. May 10, 2017).

${ }^{275}$ See Davison v. Loudoun Cnty. Bd. of Supervisors, 267 F. Supp. 3d 702, 714 (E.D. Va. May 10, 2017).

${ }^{276}$ See Davison v. Loudoun Cnty. Bd. of Supervisors, 267 F. Supp. 3d 702, 714 (E.D. Va. May 10, 2017).

277 See Davison v. Loudoun Cnty. Bd. of Supervisors, 267 F. Supp. 3d 702, 714 (E.D. Va. May 10, 2017).

${ }^{278}$ See Davison v. Loudoun Cnty. Bd. of Supervisors, 267 F. Supp. 3d 702, 714 (E.D. Va. May 10, 2017).

279 See Davison v. Loudoun Cnty. Bd. of Supervisors, 267 F. Supp. 3d 702, 714-18 (E.D. Va. May 10, 2017).
}

${ }^{280}$ See Davison v. Loudoun Cnty. Bd. of Supervisors, 267 F. Supp. 3d 702, 718 (E.D. Va. May 10, 2017). 
government may open a forum for speech by creating a website in which private viewers could "express opinions or post information" or otherwise where the government "invite[s] or allow[s] private persons to publish information or their positions." ${ }^{281}$ Referring to the facts and circumstances surrounding the creation of Randall's Facebook page, the district court found that Randalls had done just that. ${ }^{282}$ Citing the Supreme Court's decision in Packingham v. North Carolina, the district court held that "[w]hen one creates a Facebook page, one generally opens a digital space for the exchange of ideas and information." ${ }^{283}$ The court noted that Randall explicitly allowed and invited public comment on her Facebook page when she expressly solicited comments from her constituents by stating: "Everyone, could you do me a favor. I really want to hear from ANY Loudoun citizen on ANY issues, request, criticism, compliment, or just your thoughts." ${ }^{284}$ Specifically, Commissioner Randall invited her constituents to initiate and engage in "back and forth conversations" with her on "ANY issues" on the page. ${ }^{285}$ The court properly held that this language and this open invitation constituted the "designation of a place or channel of communication for use by the public,” which created a public forum for speech. ${ }^{286}$ Because Randall "allowed virtually unfettered discussion” and "affirmatively solicited comments from her constituents” on her Facebook page, Randall created a public forum for private speech that was subject to the strictures of the First Amendment. ${ }^{287}$ Accordingly,

\footnotetext{
${ }^{281}$ Davison v. Loudoun Cnty. Bd. of Supervisors, 267 F. Supp. 3d 702, 716 (E.D. Va. May 10, 2017) (quoting Page v. Lexington Cnty. Sch. Dist. One, 531 F.3d 275, 284 (4th Cir. 2008)).

${ }^{282}$ See Davison v. Loudoun Cnty. Bd. of Supervisors, 267 F. Supp. 3d 702, 716 (E.D. Va. May 10, 2017).

${ }^{283}$ Davison v. Loudoun Cnty. Bd. of Supervisors, 267 F. Supp. 3d 702, 716 (E.D. Va. May 10, 2017) (citing Packingham v. North Carolina, 137 S. Ct. 1730, 1735 (2017)).

${ }^{284}$ Davison v. Loudoun Cnty. Bd. of Supervisors, 267 F. Supp. 3d 702, 716 (E.D. Va. May 10, 2017).

${ }^{285}$ Davison v. Loudoun Cnty. Bd. of Supervisors, 267 F. Supp. 3d 702, 716 (E.D. Va. May 10, 2017).

${ }^{286}$ Davison v. Loudoun Cnty. Bd. of Supervisors, 267 F. Supp. 3d 702, 716 (E.D. Va. May 10, 2017).

${ }^{287}$ Davison v. Loudoun Cnty. Bd. of Supervisors, 267 F. Supp. 3d 702, 716 (E.D. Va. May 10, 2017).
} 
Randall's actions of deleting Davison's comments because of her disagreement with him constituted illegal viewpoint discrimination within a public forum. ${ }^{288}$

C. The President's Twitter Account as Public Forum: Knight Institute v. Donald J. Trump

In Knight Institute v. Trump, seven individuals who were blocked from following the president on his Twitter account sued the president and other responsible government officials, claiming that their First Amendment rights were violated by these actions. ${ }^{289}$ In this case, the parties dispute whether the interactive space within Trump’s @realDonaldTrump Twitter account constitutes a public forum within which viewpoint discrimination is illegal. ${ }^{290}$ The Knight First Amendment Institute, which represents seven individuals who were blocked by Trump from following him on his@RDT Twitter account, contends that the @RDT account constitutes state action, not Trump’s private action; that such state action does not constitute government speech that is immune from analysis under the Free Speech Clause, but rather that the interactive space associated with this account constitutes a designated public forum within which viewpoint discrimination is prohibited. ${ }^{291}$ President Trump and the other named defendants, on the other hand, argue that his @RDT account constitutes his private speech, so he is entitled to say what he wants and to block whatever comments he wants; that it is Twitter, a private company, not Trump, that enables the blocking of certain individuals from the president's account; and that if, in the alternative, the account constitutes state action not private action, his

\footnotetext{
${ }^{288}$ Davison v. Loudoun Cnty. Bd. of Supervisors, 267 F. Supp. 3d 702, 716 (E.D. Va. May 10, 2017). ${ }^{289}$ See Knight First Amendment Inst. at Columbia Univ. v. Trump, 302 F. Supp. 3d 541, 549 (S.D.N.Y. 2018).

${ }^{290}$ See Knight First Amendment Inst. at Columbia Univ. v. Trump, 302 F. Supp. 3d 541, 564 (S.D.N.Y. 2018).

${ }^{291}$ See Cross-Motion of Plaintiff for Summary Judgment and Opposition to Defendant's Motion for Summary Judgment at 12-21, Knight First Amendment Inst. at Columbia Univ. v. Trump, 302 F. Supp. 3d 541 (S.D.N.Y. 2018) (No. 1:17 Civ. 05205).
} 
account constitutes government speech that is immune from analysis under the Free Speech Clause (and the public forum doctrine). ${ }^{292}$ I explore each of these claims in detail below.

Both sides in the Trump/Twitter case agree that the 140 (now 280) characters that make up each presidential tweet from the @realDonaldTrump account constitute private speech in which the president enjoys his own First Amendment rights to say what he wants and that the president is constitutionally permitted to discriminate on the basis of viewpoint in composing his tweets. ${ }^{293}$ And plaintiffs do not seek to regulate the content or viewpoint of the tweets themselves. ${ }^{294}$ The disputed issue is not with the tweets themselves; rather, it involves the interactive space associated within the president's Twitter account, the space that allows Twitter users to interact with the president and with one another in relation to the president's tweets. ${ }^{295}$ As both sides stipulate, “Twitter is called a 'social' media platform in large part because of comment threads, which reflect multiple overlapping 'conversations' among and across groups of users.” ${ }^{296}$ Plaintiffs claim that they have a right to access -- and to not be blocked on the basis of viewpoint from accessing -- this interactive space, because this interactive space constitutes a

\footnotetext{
292 See Motion of Government for Summary Judgment at 10-22, Knight First Amendment Inst. at Columbia Univ. v. Trump, 302 F. Supp. 3d 541 (S.D.N.Y. 2018) (No. 1:17 Civ. 05205). The defendants also contend that the Knight Institute does not have standing to bring the lawsuit, because it has not suffered a concrete and particularized injury in fact that can be traced to the challenged actions of the president, and that the court cannot issue equitable relief against the president. See id. at 5-7. See also Knight First Amendment Inst. at Columbia Univ. v. Trump, 302 F. Supp. 3d 541, 563-64 (S.D.N.Y. 2018) (rejecting challenges to the Knight Institute's standing)

${ }^{293}$ See Motion of Government for Summary Judgment at 14, Knight First Amendment Inst. at Columbia Univ. v. Trump, 302 F. Supp. 3d 541 (S.D.N.Y. 2018) (No. 1:17 Civ. 05205); Cross-Motion of Plaintiff for Summary Judgment and Opposition to Defendant's Motion for Summary Judgment at 26, Knight First Amendment Inst. at Columbia Univ. v. Trump, 302 F. Supp. 3d 541 (S.D.N.Y. 2018) (No. 1:17 Civ. 05205).

${ }^{294}$ See Cross-Motion of Plaintiff for Summary Judgment and Opposition to Defendant's Motion for Summary Judgment at 26, Knight First Amendment Inst. at Columbia Univ. v. Trump, 302 F. Supp. 3d 541 (S.D.N.Y. 2018) (No. 1:17 Civ. 05205) (“The mere fact that @realDonaldTrump’s tweets constitute government speech does not mean that the comment threads associated with is tweets are something other than a public forum.”).

${ }^{295}$ See Knight First Amendment Inst. at Columbia Univ. v. Trump, 302 F. Supp. 3d 541, 556 (S.D.N.Y. 2018).

${ }^{296}$ See Knight First Amendment Inst. at Columbia Univ., 302 F. Supp. 3d at551 (S.D.N.Y. 2018).
} 
government-controlled, designated public forum for speech, in which viewpoint discrimination is prohibited. $^{297}$

Accordingly, the central issue in the Trump/Twitter case is whether the interactive space associated with the president’s @RDT Twitter account constitutes a designated public forum in which viewpoint discrimination is prohibited. ${ }^{298}$ Trump and the other defendants argue that the interactive space associated with Trump’s account constitutes private action, not state action. ${ }^{299}$ As County Commission Randall argued in her case, defendants in the Trump/Twitter case argue that the president's operation of his social media account is not action that is traceable to his official powers because: he does not operate the account by virtue of federal law; his use of the account is not a right conferred by the presidency; and this account itself was created before he became president. ${ }^{300}$ Defendants contend that decisions regarding which voices to allow in the interactive space associated with the president's Twitter account are similar to the president's decisions regarding whom to interact with in real space, which is a matter of private action not state action. ${ }^{301}$ Defendants contend further that the power to block constituents from the interactive space associated with the president’s Twitter account was granted and enabled by Twitter (a private entity) and is governed by Twitter's structural rules and regulations, not by the

\footnotetext{
${ }^{297}$ See Cross-Motion of Plaintiff for Summary Judgment and Opposition to Defendant's Motion for Summary Judgment at 22, Knight First Amendment Inst. at Columbia Univ. v. Trump, 302 F. Supp. 3d 541 (S.D.N.Y. 2018) (No. 1:17 Civ. 05205).

${ }^{298}$ See Knight First Amendment Inst. at Columbia Univ., 302 F. Supp. 3d at 556.

${ }^{299}$ See Motion of Government for Summary Judgment at 11, Knight First Amendment Inst. at Columbia Univ. v. Trump, 302 F. Supp. 3d 541 (S.D.N.Y. 2018) (No. 1:17 Civ. 05205) (“[T]he President's use of his personal Twitter account is among the 'acts of officers in the ambit of their personal pursuits [that] are plainly excluded’ from state action.”) (quoting Pitchell v. Callan, 13 F.3d 545, 548 (2d Cir. 1994)).

${ }^{300}$ See Motion of Government for Summary Judgment at 12, Knight First Amendment Inst. at Columbia Univ. v. Trump, 302 F. Supp. 3d 541 (S.D.N.Y. 2018) (No. 1:17 Civ. 05205).

${ }^{301}$ See Motion of Government for Summary Judgment at 13, Knight First Amendment Inst. at Columbia Univ. v. Trump, 302 F. Supp. 3d 541 (S.D.N.Y. 2018) (No. 1:17 Civ. 05205) (analogizing what Trump’s choice of what Twitter accounts to follow and block to Trump's decision of "what newspapers to pick up [and] what news programs to watch”).
} 
president. ${ }^{302}$ Accordingly, defendants claim that decisions regarding the contours of and access to the interactive space associated with the president's Twitter account are the result of private actions -- the action of Donald J. Trump not clothed in the official powers of the presidency and the action of Twitter, a private company, in creating the ability to block individuals from one's Twitter account. ${ }^{303}$

Furthermore, defendants argue, in the alternative, that if the decisions regarding the contours of the interactive space associated with @realDonaldTrump are not considered private speech, they should be considered government speech, which is immune from analysis under the Free Speech Clause and under the public forum doctrine. ${ }^{304}$ Defendants compare the president's decisions regarding who is allowed to follow him to the government's decisions in Pleasant Grove v. Summum regarding which privately donated monuments to allow in a public park. ${ }^{305}$ As in Summum, discussed above, defendants argue that the president's choices regarding conversations in response to his tweets constitute government speech. ${ }^{306}$

Finally, defendants argue that the interactive space associated with Trump’s Twitter account is not a public forum because it is property controlled by Twitter, a private company, not property that is owned and controlled by the government. They further claim that Trump has not intentionally opened up this space for public discourse, as is necessary to create a designated

\footnotetext{
${ }^{302}$ See Motion of Government for Summary Judgment at 13, Knight First Amendment Inst. at Columbia Univ. v. Trump, 302 F. Supp. 3d 541 (S.D.N.Y. 2018) (No. 1:17 Civ. 05205)

${ }^{303}$ See Motion of Government for Summary Judgment at 12, Knight First Amendment Inst. at Columbia Univ. v. Trump, 302 F. Supp. 3d 541 (S.D.N.Y. 2018) (No. 1:17 Civ. 05205)

${ }^{304}$ See Motion of Government for Summary Judgment at 15, Knight First Amendment Inst. at Columbia Univ. v. Trump, 302 F. Supp. 3d 541 (S.D.N.Y. 2018) (No. 1:17 Civ. 05205)

305 See Motion of Government for Summary Judgment at 15, Knight First Amendment Inst. at Columbia Univ. v. Trump, 302 F. Supp. 3d 541 (S.D.N.Y. 2018) (No. 1:17 Civ. 05205)

${ }^{306}$ See discussion supra.
} 
public forum. ${ }^{307}$ Rather, defendants argue, Trump’s Twitter account and the interactive space associated with it is merely the speech of the president participating in a privately run and privately controlled forum, which is not susceptible to analysis under the public forum doctrine. $^{308}$

In Knight First Amendment Institute v. Trump, the district court began its examination of the plaintiffs' public forum claims and defendant's defenses, consistent with the Supreme Court's teachings on the subject, by focusing on the nature of the access sought by plaintiffs and the type of space to which they sought access. ${ }^{309}$ The court explained that in order to analyze plaintiffs' public forum claims, it must begin by focusing on the access sought by the speakers. ${ }^{310}$ The court found that the access sought by the Trump/Twitter plaintiffs was narrow and specific in scope, similar to the access sought by the plaintiffs in the Cornelius v. NAACP ${ }^{311}$ and Perry Education Association ${ }^{312}$ public forum cases, discussed above. ${ }^{313}$ In particular, the access sought by the Trump/Twitter plaintiffs was not the right to access the president’s @RDT Twitter account as a whole, which would include the right to decide the content of the president's tweets ${ }^{314}$ and/or the

\footnotetext{
${ }^{307}$ See Motion of Government for Summary Judgment at 12, Knight First Amendment Inst. at Columbia Univ. v. Trump, 302 F. Supp. 3d 541 (S.D.N.Y. 2018) (No. 1:17 Civ. 05205)

${ }^{308}$ See Motion of Government for Summary Judgment at 13, Knight First Amendment Inst. at Columbia Univ. v. Trump, 302 F. Supp. 3d 541 (S.D.N.Y. 2018) (No. 1:17 Civ. 05205)

${ }^{309}$ See Knight First Amendment Inst. at Columbia Univ., 302 F. Supp. 3d at 565.

${ }^{310}$ See Knight First Amendment Inst. at Columbia Univ., 302 F. Supp. 3d at 565.

${ }^{311}$ See Cornelius v. NAACP Legal Def. \& Edu. Fund, 473 U.S. 788, 793 (1985) (addressing access to the Combined Federal Campaign).

${ }^{312}$ See Perry Educ. Ass'n v. Perry Local Educators' Ass'n, 460 U.S. 37, 39 (1983) (addressing access to the interschool mail system and teacher mailboxes in the Perry Township schools).

${ }^{313}$ See Knight First Amendment Inst. at Columbia Univ., 302 F. Supp. 3d at 566.

314 The court explained, not surprisingly, that the content of each tweet from the @RDT twitter account fell comfortably within the category of government speech, since these tweets consist solely of the speech of the president or other government officials who help him craft such tweets. See Knight First Amendment Inst. at Columbia Univ., 302 F. Supp. 3d at 571. However, the court went on to determine that the same could not be said of the interactive space for replies and retweets associated with each tweet sent from the @RDT account, as discussed infra. See id. at 572.
} 
right to decide whom the president follows on his @RDT Twitter account. ${ }^{315}$ Rather, the access the Trump/Twitter plaintiffs sought was the narrow and specific right to express themselves within the interactive space associated with each of the president's tweets by replying to, retweeting, and/or liking those tweets and otherwise participating in the account's interactive space -- the right that is enjoyed by the 53 million other individuals who follow the president on his @RDT Twitter account. ${ }^{316}$ Thus, the court appropriately narrowed the relevant inquiry and found that the proper subject of the forum analysis was not the @RDT Twitter account as a whole but the interactive space associated with each of the president's tweets from this account - the space that allows for the president's 53 million Twitter followers to engage and interact with, comment on, praise, criticize, expound upon, and accept or reject the statements made by the president. ${ }^{317}$

The court then examined whether this specific forum -- the interactive space associated with each of the president's tweets from his @RDT account -- constituted a forum that was government-controlled. ${ }^{318}$ The judge rejected at the outset the arguments advanced by Trump -that because the underlying forum was owned by Twitter, a private company, and was not a physical place, it did not constitute a public forum for purposes of First Amendment analysis. ${ }^{319}$ While recognizing that many of the Supreme Court's public forum cases involve governmentowned physical property like streets, parks, and public school facilities, the court explained that public forums have also been recognized in cases where the forum at issue was owned by private

\footnotetext{
315 See Knight First Amendment Inst. at Columbia Univ., 302 F. Supp. 3d at 565.

${ }^{316}$ See Complaint at 25, Knight First Amendment Inst. at Columbia Univ. v. Trump, 302 F. Supp. $3 d 541$ (S.D.N.Y. 2018) (No. 1:17 Civ. 05205). See also Donald J. Trump (@realDonaldTrump), Twitter, https://twitter.com/realDonaldTrump.

317 See Knight First Amendment Inst. at Columbia Univ., 302 F. Supp. 3d at 566.

318 See Knight First Amendment Inst. at Columbia Univ., 302 F. Supp. 3d at 566-70.

${ }^{319}$ See Knight First Amendment Inst. at Columbia Univ., 302 F. Supp. 3d at 566.
} 
entities but controlled by the government. ${ }^{320}$ As discussed above, ${ }^{321}$ in cases like Southeastern Promotions v. Conrad, the Supreme Court found that a privately-owned theater space to which access was controlled by the government constituted a public forum, notwithstanding the fact that the city did not own the forum for expression at issue. ${ }^{322}$ The judge correctly held that the underlying form of ownership of the forum is not dispositive; ${ }^{323}$ rather, the relevant inquiry concerns the entity that is exercising control over access to the forum. ${ }^{324}$ In addition, the court explained that it was irrelevant that the forum under consideration (the interactive space associated with Trump's Twitter account) did not have a physical situs, as the Supreme Court has repeatedly explained that a public forum may "lack a physical situs" 325 and may be "a forum more in the metaphysical sense than in a spatial or geographic sense." ${ }^{326}$ The court held that the non-physical forum at issue in the Trump/Twitter case was one that was governmentcontrolled. ${ }^{327}$ While recognizing that Twitter controls the basic features of the Twitter platform, the court found that it was Trump (and government officials working under his direction) who

\footnotetext{
${ }^{320}$ See Knight First Amendment Inst. at Columbia Univ., 302 F. Supp. 3d at 566.

${ }^{321}$ See text accompanying notes $\mathrm{x}-\mathrm{y}$.

322 See Knight First Amendment Inst. at Columbia Univ., 302 F. Supp. 3d at 566 (using examples of privately-owned public forums) (citing Promotions, Ltd. v. Conrad, 420 U.S. 546, 555 (1975)).

${ }^{323}$ It is worthwhile to recall language from the Supreme Court's seminal public forum case, in which it instructed that the issue of who held formal title to the property at issue was not dispositive: "Wherever the title of streets and parks may rest, they have immemorially been held in trust for the use of the public, and time out of mind, have been used for purposes of assembly, communicating thoughts between citizens, and discussing public questions. [Therefore,] the privilege of a citizen of the United States to use the streets and parks for communication of views on national questions ... must not, in the guise of regulation, be abridged or denied.” Hague v. Committee for Indus. Org., 307 U.S. 496, 515-16 (1939) (emphasis added).

${ }^{324}$ See Knight First Amendment Inst. at Columbia Univ., 302 F. Supp. 3d at 566 ("This requirement of governmental control, rather than complete governmental ownership, is . . . consistent with forum analysis's focus on 'the extent to which the Government can control access' to the space and whether that control comports with the First Amendment”) (quoting Cornelius v. NAACP Legal Def. \& Edu. Fund, 473 U.S. 788, 800 (1985)).

${ }^{325}$ See Knight First Amendment Inst. at Columbia Univ., 302 F. Supp. 3d at 566 (quoting Cornelius, 473 U.S. at 801).

${ }^{326}$ See Knight First Amendment Inst. at Columbia Univ., 302 F. Supp. 3d at 566 (quoting Rosenberger, 515 U.S. 819, 830 (1995)).

327 See Knight First Amendment Inst. at Columbia Univ., 302 F. Supp. 3d at 566.
} 
exercises control over access to the specific forum at issue in this case, including which of the 53 million individuals who follow Trump's account will be blocked from further participation in the interactive space associated with the president's tweets. ${ }^{328}$

The central issue that the court next considered was whether the government-controlled forum at issue -- the interactive space associated with each of the president's tweets from his @RDT twitter account -- was subject to forum analysis under the First Amendment or instead constituted government speech that was immune from forum analysis under the First Amendment. ${ }^{329}$ In analyzing this crucial government speech versus forum analysis issue, the court turned to the central cases of Pleasant Grove v. Summum, ${ }^{330}$ Walker v. Sons of the Confederate Veterans, ${ }^{331}$ and Matal v. Tam, ${ }^{332}$ in which the Supreme Court found the following factors to be most relevant to resolving this issue: (1) whether the forum was constrained by inherent selectivity and scarcity, including whether a public forum classification would "lead almost inexorably to the closing of the forum"333 or whether the forum was "capable of accommodating a large [amount of speech] without defeating its essential function”334; (2) whether the speech within the forum was closely identified in the public mind with the

\footnotetext{
${ }^{328}$ See Knight First Amendment Inst. at Columbia Univ., 302 F. Supp. 3d at 566-67 (“[T]hey control the content of the tweets. . . and they hold the ability to prevent, through blocking, other Twitter users ... from accessing the @realDonaldTrump account ....”).

${ }^{329}$ See Knight First Amendment Inst. at Columbia Univ., 302 F. Supp. 3d at 570.

330555 U.S. 460 (2009).

331135 S. Ct. 2239 (2015).

332137 S. Ct. 1744 (2017).

${ }^{333}$ See Knight First Amendment Inst. at Columbia Univ., 302 F. Supp. 3d at 571 (quoting Pleasant Grove City v. Summum, 555 U.S. 460, 480 (2009)).

${ }^{334}$ See Knight First Amendment Inst. at Columbia Univ., 302 F. Supp. 3d at 570 (quoting Summum, 555 U.S. at 478).
} 
government; ${ }^{335}$ and (3) whether the government maintained control over the speech in the forum. ${ }^{336}$

Applying the first factor -- whether the forum was constrained by inherent selectivity and scarcity -- the court properly held that the forum composed of the interactive space associated with each presidential tweet was not characterized by inherent selectivity and scarcity. ${ }^{337}$ This forum was distinctly unlike the forum to which plaintiffs sought access in the Summum case (namely, access to a public park for the purpose of donating and erecting permanent monuments), such that application of the forum doctrine to the access sought by Summum would “almost inexorably lead to the closing of the forum."338 Unlike the right of access to a public park to erect permanent monuments, the Trump/Twitter plaintiffs' requested access was to a forum that is capable of accommodating -- and regularly does accommodate -- an unlimited amount of speech in the form of replies and retweets. ${ }^{339}$

In considering the second factor -- whether the speech in the forum was closely identified in the public mind with the government -- the court properly found that while the president's tweets themselves were identified in the public mind with the president, the same could not be said for the interactive space (individuals' replies, retweets, likes, etc.) associated with each presidential tweet. ${ }^{340}$ Notably, each reply to a presidential tweet is associated and displayed with the account information (including the picture, name, and Twitter handle) of the replying user

\footnotetext{
${ }^{335}$ See Knight First Amendment Inst. at Columbia Univ., 302 F. Supp. 3d at 571.

${ }^{336}$ See Knight First Amendment Inst. at Columbia Univ., 302 F. Supp. 3d at 570 (quoting Matal, 137 S. Ct. at 1760).

${ }^{337}$ See Knight First Amendment Inst. at Columbia Univ., 302 F. Supp. 3d at 572.

338 See Summum, 555 U.S. at 480.

${ }^{339}$ See Knight First Amendment Inst. at Columbia Univ., 302 F. Supp. 3d at 573.The record showed that each tweet from @realDonaldTrump regularly engenders tens of thousands and upwards of hundreds of thousands of replies and retweets. Stipulation Paras. 41-43.

${ }^{340}$ See Knight First Amendment Inst. at Columbia Univ., 302 F. Supp. 3d at 572.
} 
and is not endorsed in any way by the government. ${ }^{341}$ Unlike the specialty license plates involved in the Walker case -- in which each specialty plate, in addition to bearing the specialty message, also had "TEXAS" prominently displayed on it, and was issued by the state as a form of official identification ${ }^{342}$-- and unlike the permanent monuments accepted for display within the public park in Summum, ${ }^{343}$ the reply tweets at issue in the Trump/Twitter case are not associated in the public mind with the government. ${ }^{344}$ Rather, the speech at issue in the Trump/Twitter case is more akin to the speech at issue in Matal v. Tam ${ }^{345}$-- the trademarks that private entities create and seek to secure for protection by the Patent and Trademark Office -which the Court found to be associated in the public mind with private speakers, not with the government, and to be private speech not government speech. ${ }^{346}$

Finally, in evaluating whether the interactive space associated with each presidential tweet constituted government speech, the court examined the third factor -- whether the government maintained control over the speech in the forum. ${ }^{347}$ The court observed that each reply tweet to a presidential tweet is controlled solely by the replying user herself, such that no other Twitter user (including the president) can alter the content of any reply, and that the government maintains no control over reply tweets (other than wielding the power to block the

\footnotetext{
${ }^{341}$ See Knight First Amendment Inst. at Columbia Univ., 302 F. Supp. 3d at 572 (emphasizing the "prominence” of the replying user's account information in the replying tweet).

${ }^{342}$ See Walker v. Tex. Div., Sons of Confederate Veterans, Inc., 135 S. Ct. 2239, 2248 (2015) (emphasizing the "clear governmental nature of the plates").

${ }^{343}$ See Summum, 555 U.S. at 472 (finding clear government speech in the monuments that "the City decided to accept”).

${ }^{344}$ See Knight First Amendment Inst. at Columbia Univ., 302 F. Supp. 3d at 572 ("[T]he reply is unlikely to be 'closely identified in the public mind' with the sender, even when the sender of the tweet being replied to is a governmental one.”) (quoting Matal v. Tam, 137 S. Ct. 1744, 1760 (2017)).

${ }^{345} 137$ S. Ct. 1744 (2017).

${ }^{346}$ See Matal, 137 S. Ct. at 1760 . Notably, the Supreme Court in Matal v. Tam warned against the government's attempt to extend the government speech doctrine to a broader and broader array of circumstances, which would have the effect of diminishing the protections of the Free Speech Clause: "[i]f private speech could be passed off as government speech by simply affixing a government seal of approval, government could silence or muffle the expression of disfavored viewpoints.” Id. at 1748.

${ }^{347}$ See Knight First Amendment Inst. at Columbia Univ., 302 F. Supp. 3d at 572.
} 
user from following the president on his @RDT Twitter account entirely). ${ }^{348}$ This is in contrast to the speech at issue on the specialty license plates in the Walker case, in which the state exercised "sole control over the design, typeface, color, and alphanumeric pattern for all license plates," and was vested by law with the final authority to approve every specialty license plate design proposal before the design could appear on a Texas plate. ${ }^{349}$ The court held that such government control of speech, which supported the conclusion in Walker that the speech at issue was government speech not private speech within a public forum, is completely lacking from the forum at issue in the Trump/Twitter case, as neither the president nor any government official has the ability to control the replies, retweets, or other speech in the interactive space associated with each presidential tweet.

In summary, applying the factors of whether the relevant forum was constrained by inherent selectivity and scarcity, whether the speech within the forum was closely identified in the public mind with the government, and whether the government maintained control over the speech in the forum, the court concluded that the interactive space associated with each presidential tweet constituted a public forum for private speech subject to the constraints of the Free Speech Clause, not government speech immune from the application of the Free Speech Clause. ${ }^{350}$

Having concluded that the interactive space associated with the president's Twitter account was not government speech and was properly subject to forum analysis under the Supreme Court's First Amendment jurisprudence, the court then turned to a determination of

\footnotetext{
348 See Knight First Amendment Inst. at Columbia Univ., 302 F. Supp. 3d at 572.

${ }^{349}$ See Walker v. Tex. Div., Sons of Confederate Veterans, Inc., 135 S. Ct. 2239, 2249 (2015) (“Texas law provides that the State 'has sole control over the design, typeface, color, and alphanumeric pattern for all license plates.' The Board must approve every specialty plate design proposal before the design can appear on a Texas plate.”) (citing §504.005; 43 Tex. Admin. Code §§217.45(i)(7)-(8), 217.52(b)). ${ }^{350}$ See Knight First Amendment Inst. at Columbia Univ., 302 F. Supp. 3d at 572.
} 
which type of forum was involved -- a traditional public forum, a designated public forum, or a nonpublic forum. ${ }^{351}$ Because the Supreme Court has strictly limited the first category to its historical confines of public streets, sidewalks, and parks, the court quickly moved to an examination of whether the forum at issue in this case fell within the second or third type of forum. ${ }^{352}$ The Supreme Court has instructed that, in distinguishing designated public forums from nonpublic forums, courts must "look to the policy and practice of the government to ascertain whether it intended to designate a place not traditionally open to assembly and debate as a public forum.”353 The requisite government intent on this point may be inferred from a number of factors, including the government's policy, past practice, the nature of the property, and its compatibility with expressive activity. ${ }^{354}$ Applying these factors to determine whether the government intended to open up the interactive space associated with each presidential tweet as a public forum, the court concluded that it did. ${ }^{355}$ Judge Buchwald explained that this interactive space is generally available to the public without limitation (except once an individual has been blocked by the president), the account was expressly designated as a means of communication with the American public at large, and the space is fully compatible with a substantial amount of expressive activity. ${ }^{356}$ As the Supreme Court recently recognized in Packingham v. North Carolina, social media sites like Twitter are the modern-day mediums through which citizens can "petition their elected representatives and otherwise engage with them in a direct manner." ${ }^{357}$ Accordingly, the court held that the interactive space associated

\footnotetext{
${ }^{351}$ See Knight First Amendment Inst. at Columbia Univ., 302 F. Supp. 3d at 573.

${ }^{352}$ See Knight First Amendment Inst. at Columbia Univ., 302 F. Supp. 3d at 573-74.

35373 U.S. 788, 802 (1985).

${ }^{354}$ See Cornelius, 473 U.S. at 802-03.

355 See Knight First Amendment Inst. at Columbia Univ., 302 F. Supp. 3d at 574.

${ }^{356}$ See Knight First Amendment Inst. at Columbia Univ., 302 F. Supp. 3d at 574.

${ }^{357}$ Packingham v. North Carolina, 137 S. Ct. 1730, 1735 (2017).
} 
with the president’s tweets on his @RDT Twitter account constituted a designated public forum for expression. ${ }^{358}$

Having determined that the space at issue constituted a designated public forum, the court readily determined that the president's blocking of the plaintiffs from following him on Twitter based on their viewpoint was unconstitutional. ${ }^{359}$ The Supreme Court has repeatedly and unequivocally held that viewpoint discrimination directed against speech that is otherwise permissible within a designated public forum is unconstitutional. ${ }^{360}$ The court explained that there was no conceivable way to interpret the president's blocking of the plaintiffs after they criticized him or his policies other than as an act of viewpoint discrimination, which is flatly illegal within a designated public forum. ${ }^{361}$ Accordingly, the court awarded the declaratory relief sought by the plaintiffs and ordered the president and the other named defendants to cease blocking the plaintiffs from the president's @RDT Twitter account because of their views. ${ }^{362}$

\section{Let Them Speak Their Minds in the Digital Town Hall: How Government Officials Can} Craft Constitutional Social Media Policies

As the discussion of the Governor Hogan, the Commissioner Randalls, and the President Trump cases indicates, government officials’ social media sites, such as Facebook pages and Twitter accounts, that facilitate comments, questions, and debate by constituents and members of

\footnotetext{
${ }^{358}$ See Knight First Amendment Inst. at Columbia Univ., 302 F. Supp. 3d at 575.

${ }^{359}$ See Knight First Amendment Inst. at Columbia Univ., 302 F. Supp. 3d at 575.

${ }^{360}$ See Knight First Amendment Inst. at Columbia Univ., 302 F. Supp. 3d at 575. See Rosenberger v. Rector Visitors of the Univ. of Va., 515 U.S. 819, 830-31 (1995), discussed supra at text accompanying notes x - y; Matal v. Tam, 137 S. Ct. 1744, 1763 (2017) ("When government creates such a forum. . . 'viewpoint discrimination' is forbidden”).

${ }^{361}$ See Knight First Amendment Inst. at Columbia Univ., 302 F. Supp. 3d at 575.

${ }^{362}$ See Knight First Amendment Inst. at Columbia Univ., 302 F. Supp. 3d at 579. Although the plaintiffs also sought injunctive relief from the court in the form of a court order mandating the unblocking of the plaintiffs from the president's @RDT Twitter account, the court declined to award such relief, in part because it concluded that declaratory relief was likely to achieve the same result as injunctive relief and in part because declaratory relief would be less intrusive on the prerogative of the executive and would be less likely to raise separation of powers concerns. See id.
} 
the public should -- and likely will -- be viewed by courts for First Amendment purposes as designated public forums, in which viewpoint discrimination by government officials is flatly prohibited. This means that deleting a constituent's critical comments is unconstitutional. This also means that wholly blocking an individual from such forums is likely to be impermissible. However, government officials can craft policies that constitutionally prohibit certain speech under certain circumstances: (1) if the forum is a limited public forum that is limited to discussion by a certain class of speakers or certain subjects and the speaker or speech falls outside these limits, or (2) if the speech itself is not protected by the First Amendment. I discuss each of these possibilities below.

Although it may be constitutionally permissible in certain circumstances for a government official to prohibit certain speech on the official's social media site, courts will most likely find that it is never constitutionally permissible to outright block an individual from such a social media site that is open to the public, even if that individual has posted off-topic or illegal speech in the past. Such an act of blocking would be deemed a prior restraint on that individual's (future) speech, which is presumptively unconstitutional. ${ }^{363}$ Although courts have upheld limited restrictions on individuals’ future speech -- such as gag orders imposed on those connected with judicial proceedings where necessary to protect fair trials ${ }^{364}$ or content-neutral, time, place, or manner injunctions imposed on individuals who have repeatedly violated the law in the past ${ }^{365}$--

\footnotetext{
${ }^{363}$ See Rosenberger, 515 U.S. at 830 Rosenberger, 515 U.S. at 830 ("Viewpoint discrimination . . . is presumed impermissible when directed against speech otherwise within the forum's limitations."). ${ }^{364}$ See e.g., Neb. Press Ass'n v. Stuart, 427 U.S. 539, 570 (1976).

${ }^{365}$ See, e.g., Madsen v. Women’s Health Center, Inc., 512 U.S. 753, 757 (1994) (upholding certain content-neutral provisions of a state court injunction that prohibited particular anti-abortion protestors from demonstrating and engaging in other advocacy efforts near abortion clinics and the homes of clinic employees); Schenck v. Pro-Choice Network of Western New York, 519 U.S. 357, 361 (1997) (upholding certain content-neutral provisions of state court injunction issued against fifty individuals and three organizations, including fixed buffer zones which prohibited demonstrating within 15 feet of abortion clinic doorways, parking lots, and driveways).
} 
courts have never upheld the wholesale blocking of an individual from speaking in a traditional or designated public forum. Therefore, blocking an individual from a government official's social media site will likely never pass constitutional muster.

If a government official opens up her social media site for questions and comments on all subjects, a court would likely view that site as a general purpose designated public forum and would strictly scrutinize any effort to prohibit speech within that forum on the basis of content or viewpoint. As discussed above, courts will subject speech limitations within such general purpose designated public forums to the same scrutiny as speech restrictions within traditional public forums. ${ }^{366}$ However, when the government creates or designates a public forum by opening it up for speech, it does not have to open it up for the discussion of all subjects. ${ }^{367}$ The government can create a limited-purpose designated public forum -- or a "limited public forum” - that is dedicated to the discussion of certain topics and/or that is available only for a certain class of speakers. ${ }^{368}$ For example, a school district can constitutionally limit after-school use of school property to social, civic, educational, and recreational uses, while prohibiting political or

${ }^{366}$ See Int'l Soc'y for Krishna Consciousness, 505 U.S. 672, 678 (1992). The Perry court explained: In [traditional public forums or] quintessential public forums, ... [f]or the State to enforce a content-based exclusion, it must show that its regulation is necessary to serve a compelling state interest and that it is narrowly drawn to achieve that end. ......[Similarly,] the Constitution forbids a State to enforce certain exclusions from a [designated public] forum generally open to the public even if it was not required to create the forum in the first place. Although a State is not required to indefinitely retain the open character of the facility, as long as it does so, it is bound by the same standards as apply in a traditional public forum.... [A] content-based prohibition must be narrowly drawn to effectuate a compelling state interest.... Perry Educ. Ass'n v. Perry Local Educators' Ass'n, 460 U.S. 37, 45-46 (1983).

${ }^{367}$ See Cornelius v. NAACP Legal Def. \& Edu. Fund, 473 U.S. 788, 806 (1985) (“Control over access to a nonpublic forum can be based on subject matter and speaker identity so long as the distinctions drawn are reasonable in light of the purpose served by the forum and are viewpoint neutral) (citing Perry Educ. Ass'n, 460 U.S. at 49).

${ }^{368}$ See Lamb's Chapel v. Ctr. Moriches Union Free Sch. Dist., 508 U.S. 384, 390 (1993) (describing a limited public forum as "open only for designated purposes”). 
commercial uses of such property. ${ }^{369} \mathrm{~A}$ city council can create an open microphone opportunity during a council meeting and allow speakers to address any issue on the council's agenda, but prohibit discussion of topics that are not on the council's agenda. A state university can open up its classrooms for use by student organizations, but not by outside community groups. Such topic-based or speaker-based restrictions within limited purpose public forums are constitutional, so long as any prohibitions on speech within the limited public forum are also reasonable in light of the purposes and subjects of the forum and are not based on viewpoint. By expressly creating such a limited-purpose public forum, the government officials would be empowered to prohibit speech that fell outside of such topics, such as commercial advertisements. Similarly, a government official could open up a Facebook page or Twitter account's forums to speech on political and public interest topics, while prohibiting commercial advertisements or solicitation, for example, within that forum.

In addition, when government officials use social media sites, such as Facebook pages and Twitter accounts, that invite questions, comments, and debate by constituents and members of the public, they may constitutionally prohibit speech that is outside the protection of the First Amendment, including speech that amounts to a true threat, ${ }^{370}$ speech that constitutes fighting

\footnotetext{
${ }^{369}$ See Lamb's Chapel, 508 U.S. at 391-92 (holding that while it is constitutional to create a designated public forum with such limited purposes as social, civic, and recreational uses, it is unconstitutional to prohibit religious uses of such property); Good News Club v. Milford Central School, 553 U.S. 98, 10809 (2001) (holding that while it is constitutional to create a designated public forum with such limited purposes as instruction in education, learning, the arts, social, civic, recreational, and entertainment uses pertaining to the community welfare, it is unconstitutional to prohibit the use of the property for religious purposes.)

370 True threats -- statements where the speaker means to communicate a serious expression of an intent to commit an act of unlawful violence to a particular individual or group of individuals -- are statements that are not protected by the First Amendment. See, e.g., Virginia v. Black, 538 U.S. 343 (2003). However, threatening speech regarding a government official may be more likely to be viewed as mere "political hyperbole" and therefore protected by the First Amendment. See Watts v. United States, 394 U.S. 705 (1969) (defendant's statement "If they ever make me carry a rifle the first man I want to get in my sights is L.B.J. [President Lyndon B. Johnson]" was not a true threat within the meaning of a statute that made it a crime to knowingly and willfully threaten the life of the president, but was rather a "kind of political
} 
words, ${ }^{371}$ speech that is obscene, ${ }^{372}$ and speech that contains child pornography. ${ }^{373}$ While speech within the last two categories (obscenity and child pornography) is less likely to be posted on a government official's social media site, and while the second category of unprotected speech (fighting words) appears to be an anachronism, ${ }^{374}$ it is not unrealistic to expect that speech that arguably falls within the first category of unprotected speech -- true threats -- would be posted in an online forum, and the government official who hosts the forum may constitutionally prohibit such speech. However, the ultimate determination of the illegality of any such post must await a judicial determination, since speech cannot be censored by a government official prior to a judicial determination of its illegality, pursuant to the prior restraint doctrine. ${ }^{375}$ Under the prior hyperbole" and a "crude offensive method of stating political opposition to the president"). For a recent controversy regarding speech that was allegedly threatening to the President of the United States, consider the uproar over comedian Kathy Griffin's picture of herself holding a replica of the decapitated head of President Trump. See https://www.usatoday.com/story/news/nation/2017/05/31/did-kathy-griffin-breaklaw-her-photo-decapitated-trump/356840001/

${ }^{371}$ In the 1942 case of Chaplinsky v. New Hampshire, 315 U.S. 568 (1942), the Supreme Court held that "fighting words" -- words that "men of common intelligence would understand to be words likely to cause an average addressee to fight" -- were not protected by the First Amendment.

${ }^{372}$ In Miller v. California, the Supreme Court set forth the following three-part definition of obscene speech, which is outside the protection of the First Amendment: "(a) whether the average person, applying contemporary community standards would find that the work, taken as a whole, appeals to prurient interest; (b) whether the work depicts or describes, in a patently offensive way, sexual conduct specifically defined by the applicable state law, and (c) whether the work, taken as a whole, lacks serious literary, artistic, political, or scientific value.” 413 U.S. 15, 24 (1973). But obscenity prosecutions that do not also involve child pornography prosecutions are relatively rare. See https://www.nytimes.com/2007/09/28/us/28obscene.html (fewer than two dozen federal obscenity prosecutions have been brought that did not also involve child pornography).

${ }^{373}$ In New York v. Ferber, 458 U.S. 747 (1982), the Court held that child pornography, defined as visual depictions of minors engaged in sexual activity, was outside the protection of the First Amendment.

${ }^{374}$ Although the Supreme Court has repeatedly stated that fighting words are outside the protection of the First Amendment, since its 1942 decision in Chaplinsky, the Court has never since held that any speech actually fell within this category of unprotected speech. See, e.g., Snyder v. Phelps, 562 U.S. 442, n.3 (2011) (reiterating that the category of "fighting words" is outside the protection of the First Amendment, but holding that Westboro Baptist Church's speech at military funeral -- including posters with the words "God Hates Fags" and "God Hates You" -- did not fall within this unprotected category).

${ }^{375}$ As I have explored in great detail elsewhere, any restraint on speech that is imposed by a government official prior to a judicial determination of the speech's illegality constitutes a prior restraint on speech that is presumptively unconstitutional. See, e.g., Dawn Carla Nunziato, How (Not) To Censor: Procedural First Amendment Values and Internet Censorship Worldwide, 42 Geo. J. Int'l L. 1123 (2011); Bantam Books, Inc. v. Sullivan, 325 U.S. 58 (1963). 
restraint doctrine, any restriction on or censorship of speech by a government official prior to a judicial determination of the speech's illegality constitutes a prior restraint on speech that is presumptively unconstitutional. Therefore, even if the government official believes that the speech at issue constitutes an unprotected true threat or falls within one of the other categories of unprotected speech discussed above, removal or censorship of such speech by the government official prior to a judicial determination of the speech's illegality would constitute a presumptively illegal prior restraint. ${ }^{376}$ Accordingly, government officials have very limited authority to remove speech with the designated public forums constituted by their social media sites.

\section{Conclusion}

When government officials, like Maryland Governor Larry Hogan and President Donald J. Trump, use social media sites like Facebook and Twitter to engage and interact with their constituents on matters related to their governance, they are creating modern-day public forums for speech. Although the media itself in which these interactions take place is of recent vintage, allowing for interactions between those who govern and those who are governed has long been recognized as vital to our system of democratic self-governance. Such interactions between government officials and their constituents form the heart of our system of democratic selfgovernment and must continue to be protected from censorship in the digital age, which is why viewpoint discrimination within such forums is flatly unconstitutional under the Supreme Court's well-developed public forum jurisprudence. Despite the modern-day context of such interchanges, the interactions themselves remain at the core of the First Amendment's protections

\footnotetext{
${ }^{376}$ See, e.g., New York Times v. United States (striking down Nixon Administration's injunctions against publication of portions of The Pentagon Papers by New York Times and Washington Post, stating that "every moment's continuance of the injunctions against these newspapers [prior to judicial determination of the publication's illegality] amounts to a flagrant, indefensible, and continuing violation of the First Amendment.”) (per curiam) (Black, J., concurring).
} 
for free speech. The Court's explanation of this point remains as important today as when the Court ushered in the public forum doctrine eighty years ago:

The very idea of a government, republican in form, implies a right on the part of its citizens to [consult] in respect to public affairs and to petition for a redress of grievances. ... Such use of [public forums] has, from ancient times, been a part of the privileges, immunities, rights, and liberties of citizens. The privilege of a citizen of the United States to use [public forums] for communication of views on national questions . . . must not ... be abridged or denied. ${ }^{377}$

Whether public forums are recognized in the town square or in the Twittersphere, these forums remain vital to our system of democratic self-government and must continue to be protected from government censorship in the digital age.

${ }^{377}$ Hague v. CIO, 307 U.S. 494, 513-16 (1939). 